\title{
Lithogeochemical and $\mathrm{Nd}-\mathrm{Sr}$ isotope data of the orthogranulites of the Juiz de Fora complex, SE-Brazil: insights from a hidden Rhyacian Orogen within the Ribeira belt
}

\author{
Lucas Eduardo de Abreu Barbosa Araujo ${ }^{1 *}$ (D), Monica Heilbron ${ }^{1,2}$ (D), Claudio de Morisson Valeriano ${ }^{1,2}$ (D), \\ Wilson Teixeira ${ }^{3}$ (D), Carla Cristine Aguiar Neto' ${ }^{1}$ (D)
}

\begin{abstract}
New petrography, geochemistry and Sm-Nd and Sr data from the orthogranulites of the Juiz de Fora complex in southern Rio de Janeiro State and compiled information provide insights on the petrogenetic and tectonic evolution. The complex comprises several geochemical groups including mafic orthogranulites (three tholeiitic and one alkaline) and felsic orthogranulites (three calc-alkaline and one tholeiitic/low $\mathrm{K}$ calc-alkaline). New geochemical and isotope data, combined with available U-Pb data suggest a long evolutionary history from the Paleoproterozoic to the Neoproterozoic. The oldest magmatic episode produced juvenile to slightly contaminated arc-type Rhyacian rocks, as well as granitic rocks related to collision or post-collision episodes. Altogether these rocks integrate part of a dismembered Rhyacian orogen within the Ribeira belt. Few $\mathrm{T}_{\mathrm{DM}} \mathrm{Nd}$ model ages yielded 2.75 to $2.58 \mathrm{Ga}$, suggesting minor Archean contribution for magma genesis. Some of the basic granulites' bodies yield Meso- to Neoproterozoic $\mathrm{T}_{\mathrm{DM}} \mathrm{Nd}$ model ages, which may refer to an extensional magmatism. Orthogranulites present granulite facies paragenesis, related to the youngest tectonic episode in the Juiz de Fora Complex (Brasiliano Orogeny). The new data are potentially important for Paleoproterozoic reconstruction models, due to the predominantly juvenile character of the Juiz de Fora complex, as similarly worldwide.
\end{abstract}

KEYWORDS: Paleoproterozoic juvenile arcs; Statherian Taphrogenesis; Juiz de Fora Complex.

\section{INTRODUCTION}

The São Francisco Paleocontinent (Heilbron et al. 2000, 2004, 2008, Trouw et al.2000), is a landmass that encompasses the Archean nuclei within São Francisco-Congo and adjoining Paleoproterozoic belts. In SE Brazil, the Paleoproterozoic Mineiro, Mantiqueira and Juiz de Fora belts accreted onto the southern São Francisco Archean nuclei in the Siderian to Orosirian (Alkmim \& Teixeira 2017, Barbosa et al. 2018, Heilbron et al. 2010). This important episode of continental crust growth is ascribed to the Minas accretionary orogeny (Teixeira et al. 2014, 2015). The São Francisco-Congo Paleocontinent behaved as a stable mass until the Statherian, when an important period of bimodal intraplate magmatism and extensional tectonics resulted in the Espinhaço rift system

\section{Supplementary data}

Supplementary data associated with this article can be found in the online version: Suplementary Table A1 and Suplementary Table A2.

\footnotetext{
${ }^{1}$ Universidade do Estado do Rio de Janeiro - Rio de Janeiro (RJ), Brazil. E-mails: lucaseduardo9393@gmail.com,monica.heilbron@gmail.com, wteixeir@usp.br

${ }^{2}$ Universidade de Salzburg - Salzburg, Austria.

${ }^{3}$ Universidade de São Paulo - São Paulo (SP), Brazil. E-mail: wteixeir@usp.br ${ }^{*}$ Corresponding author.
}

C) 2019 The autors. This is an open access article distributed under the terms of the Creative Commons license.
(Babinski et al. 1994, Dussin \& Dussin 1995, Brito-Neves et al. 1995, Chemale Jr. et al. 2012).

The borders of the São Francisco Paleocontinent were deeply reworked during formation of Western Gondwana in the Neoproterozoic, highlighted by the surrounding marginal belts (Heilbron et al. 2010). In this context, the Juiz de Fora complex (JFC) represents one of these reworked basement units that crop out in the Ribeira belt. The JFC has large spatial distribution extending from the limit between the states of Rio de Janeiro and São Paulo to eastern Minas Gerais.

The JFC comprises orthogranulites and orthogneisses of wide compositional variability, and occurs as NE-trending thrust-sheets, with NW vergence and dextral lateral component, tectonically interleaved with Neoproterozoic metasedimentary rocks of the Andrelândia Group. The latter represents one of the supracrustal passive margin units of the Neoproterozoic orogenic system (Heilbron et al. 1998, 2004, Trouw et al. 2000).

The investigation of the basement inliers in the central segment of the Ribeira belt is one of the key points for understanding the nature of the Neoproterozoic orogen in SE-Brazil (Heilbron et al. 1998, 2000, 2010, Noce et al. 2007, Degler et al. 2018). In a broader view, this system includes the Araçuaí orogen to the north (Pedrosa-Soares \& Noce 1998, Pedrosa-Soares \& Wiedmann-Leonardos 2000, Pedrosa-Soares et al. 2001, 2008), and the Dom Feliciano belt to the south, as well as the West-Congo and Kaoko belts 
in Africa (Miller 1983, Seth et al. 1998, Goscombe \& Gray 2007, 2008, Goscombe et al. 2017).

In order to contribute to the understanding of the tectonic evolution of the JFC, this work brings new petrographic, geochemical and $\mathrm{Nd}-\mathrm{Sr}$ isotope data, as well as systematic geologic mapping of the JFC orthogranulites in southern Rio de Janeiro. The new data is compared with previously published $\mathrm{U}-\mathrm{Pb}$ geochronology and geochemistry works on the study area (Machado et al. 1996, Heilbron et al. 2010), as well as with regional data from the JFC (Silva et al. 2002, Noce et al. 2007, Degler et al. 2018, Kuribara et al. 2019).

\section{TECTONIC SETTING}

Ribeira Belt (Hasui et al. 1975, Trouw et al. 2000, Heilbron et al. 2000, 2004, 2008) resulted from multiple diachronic collisions during the Neoproterozoic (ca. 605-520 Ma). From NW to SE, it is divided into four tectono-stratigraphic terranes (Heilbron et al. 1998):

- Occidental Terrane, where the study area is located, considered as part of the reworked margin of São Francisco Paleocontinent;

- Paraíba do Sul-Embú Terrane, thrusted over the Occidental Terrane;

- Oriental Terrane, consisted of magmatic arc rocks and associated metasedimentary units;

- Cabo Frio Terrane, which was accreted against the Ribeira belt at ca. $520 \mathrm{Ma}$ (Schmitt et al. 2004).

Except for the Oriental Terrane, they comprise Paleoproterozoic basement associations and Meso- to Neoproterozoic metasedimentary units (Valladares et al. 2000, 2002, Heilbron et al. 2010, Schmitt et al. 2004). The collision between the Occidental and Oriental Terranes produced a conspicuous suture zone, the Central Tectonic Boundary (CTB) (Almeida et al. 1998). This sector of the Ribeira belt also contains several granitoid rocks of pre-, syn- and post collisional character (Tupinambá et al. 2012).

The Occidental Terrane (Heilbron et al. 1998) essentially comprises two basement units (Mantiqueira and Juiz de Fora complexes) and the Neoproterozoic Andrelândia Group. The Mantiqueira Complex (Heilbron et al. 1998, 2010, Noce et al. 2007, Duarte et al.2000, 2004) covers amphibolite facies orthogneisses containing layers of amphibolites and meta-ultramafic lenses (Heilbron et al.2017, Noce et al. 2007). During the convergence that produced the Ribeira Belt, two thrust systems were formed in the Occidental Terrane (Fig. 1A), playing important role in the architecture of the Mantiqueira and Juiz de Fora complexes (Heilbron et al. 2010). In the lower thrust system (Andrelândia Tectonic Domain), Mantiqueira Complex represents the basement unit, overlain by the Andrelândia Group. In the upper thrust system (Juiz de Fora Domain), supracrustal rocks represent the distal facies of the same metasedimentary unit, but tectonically interleaved with the JFC rocks.

The Juiz de Fora and Mantiqueira basement complexes show deep reworking and crustal shortening during the Neoproterozoic Brasiliano orogeny, given by structural, metamorphic and geochronological evidence (Heilbron et al. 2010, Degler et al. 2018). In particular, the JFC and interlayered supracrustal rocks underwent granulite facies metamorphism, as indicated by mineral paragenesis with peak temperatures between 800 and $895^{\circ} \mathrm{C}$ (Duarte et al. 2000, Bento dos Santos et al. 2011, Degler et al. 2018). Additionally, the JFC rocks exhibit retrograde mineral paragenesis and a pervasive mylonitic foliation, acquired during the final stages of thrusting during the Brasiliano orogeny.

Previous authors reported that the JFC orthogranulites display geochemical compositions varying from basic to acid (Heilbron et al. 1997, 1998, 2000, Duarte et al. 1997, Noce et al. 2007, Kuribara et al. 2019), with predominance of enderbitic to charnockitic granulites and subordinated basic granulites. The latter shows tholeiitic character, while felsic granulites display calc-alkaline affinity (Heilbron et al. 1998, Duarte et al. 1997). The protoliths of the basic granulites are enriched Mid Ocean Ridge Basalts (E-MORB) and Island Arc Tholeiites (IAT) gabbroic rocks formed in extensional or island arc settings. Felsic granulites are interpreted as formed in volcanic arc to syn-collisional tectonic settings (Heilbron et al. 1998, Duarte et al. 1997, Kuribara et al. 2019).

The available zircon $\mathrm{U}-\mathrm{Pb}$ crystallization ages mainly span between 2.20 to 2.07 Ga (Machado et al. 1996, Silva et al.2002, Noce et al. 2007, André et al. 2009, Heilbron et al. 2010, Degler et al.2018, Kuribara et al.2019). In contrast, some mafic granulites with documented zircon $\mathrm{U}-\mathrm{Pb}$ ages of ca. 2.4 and $1.8 \mathrm{Ga}$ show E-MORB tholeiitic and intraplate alkaline signatures, respectively (Heilbron et al. 2010). Locally, ca. 2.98 Ga-old granulite was reported nearby Juiz de Fora (Silva et al. 2002) with metamorphic age in zircon rims of 2,856 $\pm 44 \mathrm{Ma}$ ). In addition, (E-MORB tholeiitic) mafic granulites have been dated at $766 \mathrm{Ma}$, in the Miracema region (Heilbron et al. 2019, Santos 2017).

Old fashion whole rock $\mathrm{Rb}$-Sr reference isochrones, integrating several JFC outcrops, yielded ages ranging from 2.65 to $2.25 \mathrm{Ga}$ in a first attempt to unravel the tectonic history of the granulitic rocks (Delhal et al. 1969, Cordani et al. 1973). However, these ages will be not considered here, given the accuracy of the U-Pb data. In a similar manner, K-Ar ages of 1,570 to 1,220 Ma on pyroxene and plagioclase of the JFC rocks (Delhal et al. 1969, Cordani et al. 1973) have dubious or no geologic significance. In contrast, a large set of $0.62-0.52 \mathrm{Ga}$ $\mathrm{U}-\mathrm{Pb}$ ages reported for the JFC rocks better defines the age of regional metamorphic overprint (Machado et al. 1996, Noce et al. 2007, Bento dos Santos et al. 2011, André et al. 2009, Heilbron et al. 2010, Degler et al. 2018, Kuribara et al. 2019). This age interval is consistent with previously published amphibole and biotite K-Ar ages ( 615 to $497 \mathrm{Ma}$ ) for granulite rocks from Juiz de Fora and Carangola regions (Delhal et al. 1969, Cordani et al. 1973). Furthermore, in the same locations, Rb-Sr mineral isochrons yielded ages from 600 to $496 \mathrm{Ma}$, confirming the relevance of the Neoproterozoic metamorphic overprint (e.g., Cordani et al. 1973).

Previously published Sm-Nd $\mathrm{T}_{\mathrm{DM}}$ model ages for the JFC felsic granulites in the regions of Abre Campo-Manhuaçu (Minas Gerais) and Três Rios (Rio de Janeiro) vary between 
2.20 and $2.13 \mathrm{Ga}$ (Fischel et al. 1998), and 2.37 Ga (André et al. 2009), suggesting juvenile character for the Paleoproterozoic protoliths. Additional Sm-Nd model ages of 2.18 and $2.03 \mathrm{Ga}$ obtained by Degler et al. (2018) also support this hypothesis. On the other hand, significantly older $\mathrm{Sm}-\mathrm{Nd} \mathrm{T}_{\mathrm{DM}}$ model ages of 3.2 and $2.9 \mathrm{Ga}$ were reported for granulitic rocks ascribed to the JFC within the Araçuaí belt (Fischel et al. 1998). Available $\mathrm{Lu}-\mathrm{Hf} \mathrm{T}_{\mathrm{DM}}$ model ages yield results between 3.45 and $2.26 \mathrm{Ga}$, with most results related with Siderian to Rhyacian periods (Degler et al. 2018, Kuribara et al. 2019).

From a tectonic point of view, theJFC was interpreted as derived from a Paleoproterozoic intra-oceanic arc (Machado et al. 1996,
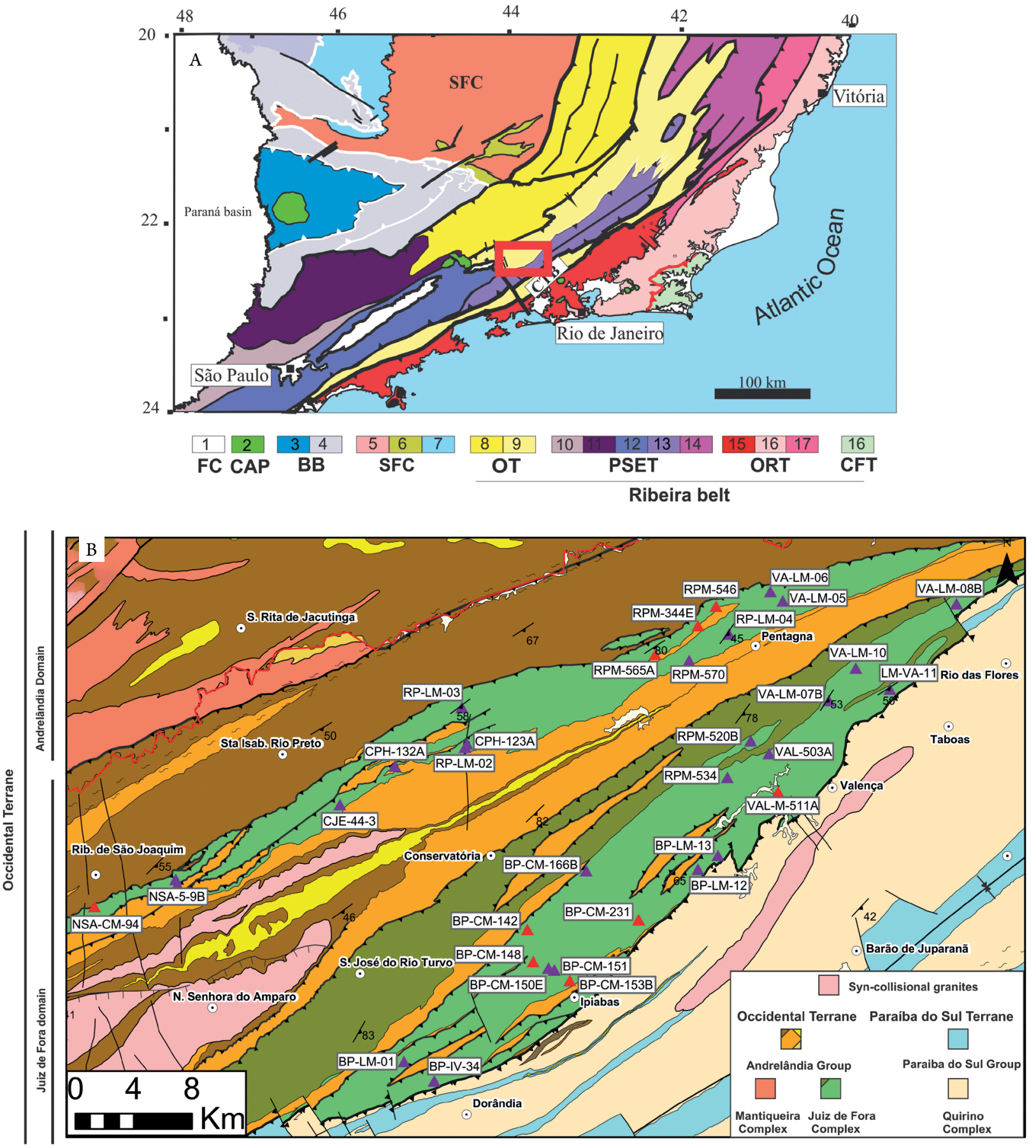

\section{Paraíba do Sul Terrane}

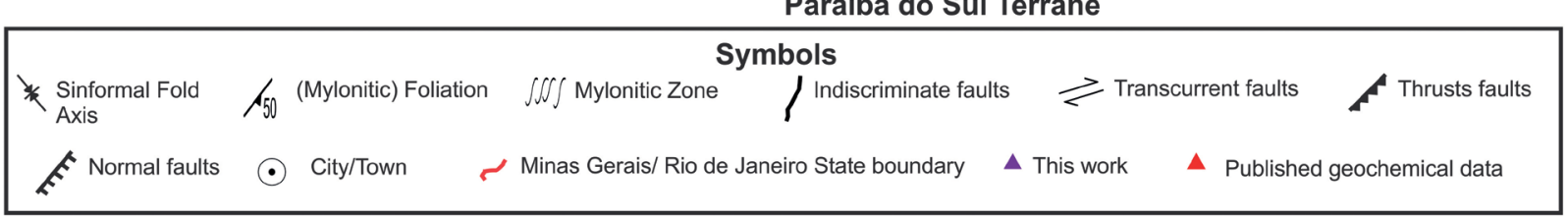

FC: Fanerozoic cover; CAP: Cenozoic Alkaline plutons; BB: Brasília belt; SFC: São Francisco Craton; OT: Occidental Terrane; PSET: Paraíba do Sul and Embú Terranes; ORT: Oriental Terrane; CFT: Cabo Frio Terrane.

Figure 1. (A) Tectonic subdivision of the Ribeira belt as proposed by Heilbron et al. (2017) with study area in the red rectangle. (B) Geological map showing the NE-SW green strips of the Juiz de Fora complex and the location of studied samples. 
Heilbron et al. 1997, 2010, Silva et al. 2002). Alternatively, Kuribara et al. (2019) argued that JFC is a volcanic arc magmatic system with two episodes of juvenile magma generation, in the Siderian and the Orosirian. These magmas were sourced by melting of a Paleoarchean microcontinent. Another crust recycling period was proposed by Kuribara et al. (2019), in continental arc magmatism on Late Neoproterozoic. Cutts et al. (2019) argued that it seems unnecessary to make up an Archean microcontinent as a part of JFC. The Archean $\mathrm{T}_{\mathrm{DM}}$ Hf model ages obtained by Kuribara et al. (2019) could be related to Archean sediments supplied from the São Francisco Craton as detrital zircons that were later subducted below the Siderian juvenile arc of JFC.

The available $\mathrm{Rb}-\mathrm{Sr}, \mathrm{K}-\mathrm{Ar}, \mathrm{U}-\mathrm{Pb}, \mathrm{Sm}-\mathrm{Nd}$ and $\mathrm{Lu}-\mathrm{Hf}$ isotope data for the JFC is summarized in the supplementary material (Suppl. Tab. A1).

\section{MATERIALS AND METHODS}

\section{Geochemistry}

Forty JFC granulite samples were selected for geochemical study. Preparation included their crushing and milling at the Laboratório de Preparação de Amostras (LGPA) of Universidade do Estado do Rio de Janeiro. Major and trace element analyses were performed by Activation Laboratories (Ontario, Canada). The analytical techniques included Lithium Metaborate/Tetraborate Fusion and ICP (MS) methodologies. Details on the analytical techniques used are presented in the laboratory website (http://www.actlabs.com/page. aspx ?menu $=74 \&$ app $=244 \&$ cat $1=595 \& \operatorname{tp}=2 \& l k=$ no).

New and previously published geochemical data (Heilbron 1993, Heilbron et al. 1998) were used in order to cover a larger spatial distribution of the JFC within the study area (Fig. 1B). Treatment of the data of different laboratories was carried out using the Geochemical Data ToolKIT (GCDkit) of Janoušek et al. (2006) and MS Excel software. For the rare earth element (REE) diagrams, the chondritic contents for normalization were compiled from Boynton (1984).

\section{$\mathrm{Sm}-\mathrm{Nd}$ and $\mathrm{Sr}$ isotopes}

For Sm-Nd and $\mathrm{Sr}$ analyses, ten basic granulites, twelve enderbites to charno-enderbites and six charnockitic granulites were selected from the same pulp of twenty-eight JFC samples used for the geochemistry study.

$\mathrm{Sm}-\mathrm{Nd}$ and $\mathrm{Sr}$ isotopic analyses were conducted in the Laboratory of Geochronology and Radiogenic Isotopes (LAGIR) of Universidade do Estado do Rio de Janeiro. Chemical procedures were carried out in clean rooms with use of sub-boiling distillation of Milli- $\mathrm{Q}^{\circledR}$ water and PA Merck ${ }^{\circledR}$ acids (Cardoso et al.2019). Between 25 and $50 \mathrm{mg}$ of the pulverized samples were subjected to digestion in Savillex ${ }^{\circledR}$ vessels on hot plates, after the addition of proportional amounts of a double ${ }^{149} \mathrm{Sm}^{-150} \mathrm{Nd}$ tracer solution. A mixture of concentrated $\mathrm{HF}$ and $\mathrm{HNO}_{3} 6 \mathrm{~N}$ was applied for 3 days, followed by further digestion with $\mathrm{HCl} 6 \mathrm{~N}$ for 2 days. Separation of $\mathrm{Sr}$ and REE used cation exchange following conventional techniques with Teflon columns filled with Biorad ${ }^{\circledR}$ AG50W-X8 resin (100-200 mesh) in $\mathrm{HCl}$ medium. For the separation of Sm and $\mathrm{Nd}$, a secondary column was used with the Eichrom LN-B-25S (50-100 $\mu \mathrm{m})$ resin. After evaporation, Sm, Nd and Sr were separately loaded onto previously degassed Re filaments assembled in double mounts, using $\mathrm{H}_{3} \mathrm{PO}_{4}$ as ionization activator. Isotope ratios were measured using a ThermoScientific TRITON thermal ionization mass spectrometer (TIMS) in static mode with up to 8 Faraday collectors. Measured isotope ratios are reported with absolute standard errors $(2 \sigma)$ below $10^{-5}$. Measured ratios were normalized respectively to the natural constant ratios of ${ }^{146} \mathrm{Nd} /{ }^{144} \mathrm{Nd}=0.7219,{ }^{147} \mathrm{Sm} /{ }^{152} \mathrm{Sm}=0.5608$ and ${ }^{88} \mathrm{Sr} /{ }^{86} \mathrm{Sr}=8.3762$. Average ${ }^{143} \mathrm{Nd} /{ }^{144} \mathrm{Nd}$ ratio of repeated measurements of the JNdi-1 standard (Tanaka et al. 2000) was $0.512098 \pm 0.000006(n=322)$. Average ${ }^{87} \mathrm{Sr} /{ }^{86} \mathrm{Sr}$ ratio of the NBS-987 standard (Wise \& Waters 2007) was $0.710239 \pm 0.000008(n=158)$. Repeated analyses of the BCR and AVG rock reference materials from the United States Geologic Survey yielded ${ }^{147} \mathrm{Sm} /{ }^{144} \mathrm{Nd}$ ratios with reproducibility within $1 \%$ (Valeriano et al. 2008). Neodymium $\left(\mathrm{T}_{\mathrm{DM}}\right.$ ) model ages were calculated using the depleted mantle model of DePaolo (1981).

\section{RESULTS}

\section{Field and petrographic observations}

The internal structure of the Juiz de Fora structural domain in the study area (Fig. 1B) is represented by a tectonic interleaving between the orthogranulites of JFC with the metasedimentary rocks of the Andrelândia Group within two NW vergent thrust sheets. A lateral dextral component attesting the oblique collision was reported by Heilbron et al. (2000). To the south, the JFC rocks are in tectonic contact with the overlaying orthogneiss of the Quirino Complex and the metasedimentary rocks of the Paraiba do Sul group that make up Paraíba do Sul Terrane (Heilbron et al. 2000, Tupinambá et al. 2007).

The JFC granulites crop out in both the lower and upper thrust sheets, respectively extending along strike for $75 \mathrm{~km}$, between the cities of Manoel Duarte (Minas Gerais) and Ribeirão de São João (Rio de Janeiro), and for $61 \mathrm{~km}$ between the cities of Rio das Flores (Rio de Janeiro) and Dorândia (Rio de Janeiro) (Fig. 1B). The outcrops are typically small quarries and road cuts. The rocks display deep green to pale brown colors depending on their primary composition and internal structure. The composition of orthogranulites varies from mafic to felsic (charno-enderbites, enderbites and charnockites) rocks, with predominance of charno-enderbites (Fig. 2A). The samples' geographic coordinates, as well as its petrographic classification, can be found in a supplementary table (Suppl. Tab. A2).

Charno-enderbites occur as the main rock type (Fig. 2B), showing coarse to medium grain size. Normally, enderbites (Fig. 2C), as a variation of charno-enderbites, present a medium to fine grain size and green darker colors. The textures of charno-enderbites and enderbites vary from granoblastic to mylonitic, depending on the location within the thrust sheet pile. Charnockites (Fig. 2D) are commonly coarse-grained pale 
light green injections or leucosomes within all rock types cited above. Typical textures are granoblastic (Fig. 3A), with massive aspect. Folded felsic granulites (Fig. 2D) occur in more deformed zones. Charnockites may also occur as the main lithotype in some outcrops, normally with pervasive foliation.

The essential mineralogy of felsic granulites (Fig. 3A) consists of plagioclase, quartz, K-feldspar, orthopyroxene (hypersthene), hornblende, biotite and (diopside) clinopyroxene. Zircon, apatite, ilmenite and magnetite are the accessory minerals. K-feldspar contents are remarkably different among felsic granulites. Charnockites are K-feldspar rich, while K-feldspar in enderbitic terms is rare. Diopside occurs only in enderbites and in some groups of charno-enderbites. Hornblende and biotite are commonly retrograde minerals in all granulitic rocks.

Mafic bands/enclaves and centimeter-thick lenses occur within felsic types (Figs. 2B, 2C and 2D), but can be distinguished as isolated mafic bodies. They show massive structure, medium to fine grain size and deep green original colors. Mafic granulites consist of plagioclase, diopside, hypersthene, hornblende and traces of quartz, with local coronitic garnet around pyroxene (Fig. 3B). Retrograde biotite, sericite and carbonates are also present. Apatite, zircon, magnetite, ilmenite and pyrite are the accessory minerals.

Textures and external colors vary as a function of deformation, with deep green colors and granoblastic textures in the center of the large thrust sheets, and pale green to whitish colors in the mylonitic varieties along the tectonic contacts with Andrelândia Group rocks. In more deformed granulites, foliation is defined by mafic minerals, with porphyroclasts of orthopyroxene surrounded by hornblende and biotite fringes (Fig. 3C). Ultramylonitic types, very common nearby the city of Conservatoria (Fig. 1B), are represented by highly stretched black and white banded gneisses with minor orthopyroxene relicts. Within felsic mylonitic types, feldspar porphyroclasts with anti-perthitic structures and quartz ribbons (Fig. 3D) are common features.

\section{Geochemistry}

Forty samples were divided into mafic and felsic granulites, according to field observation. The former with twelve samples of basic composition, and the latter with 28 samples of intermediate to acid composition. They were classified in magmatic series and then subdivided into subgroups based on REE patterns and field relationships, with four subgroups for each group.

\section{Mafic Granulites}

Mafic granulites (Tab. 1) display gabbroic composition (Cox et al. 1979) and are subdivided into the alkaline (four samples) and tholeiitic sub-alkaline (eight samples) series (Figs. 4A and B). The tholeiitic trend is marked by iron enrichment in the AFM diagram of Figure 4B (Irvine \& Baragar 1971).
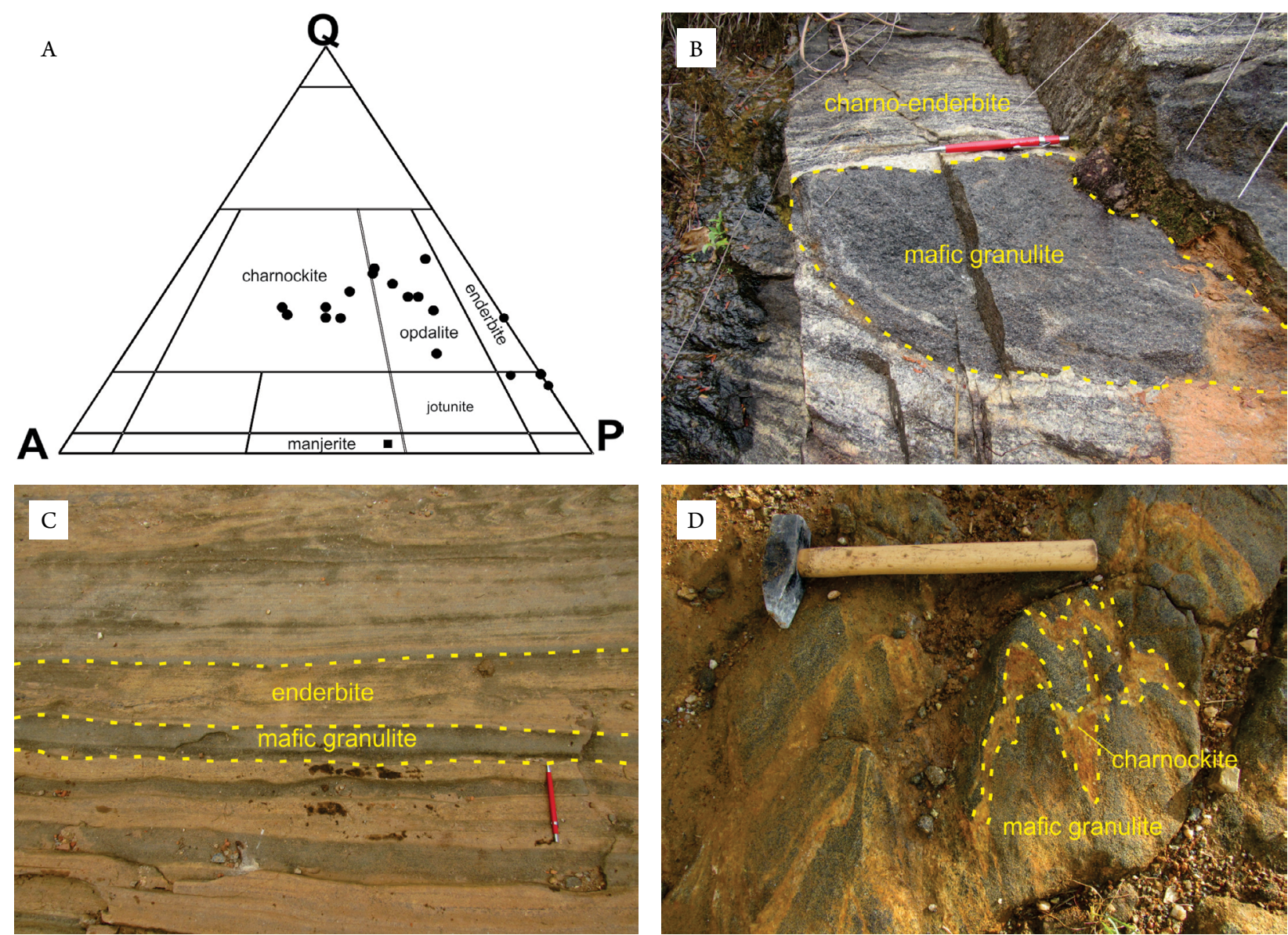

Figure 2. Field aspects of the orthogranulites of the JFC: (A) QAP petrographic diagram (Streckeisen 1974) for the felsic granulites of the studied area; (B) Charnoenderbites with band/enclave of the mafic granulites; (C) Deformed strips of mafic granulites within enderbites; (D) Mafic granulite with folded charnockite leucosomes. 

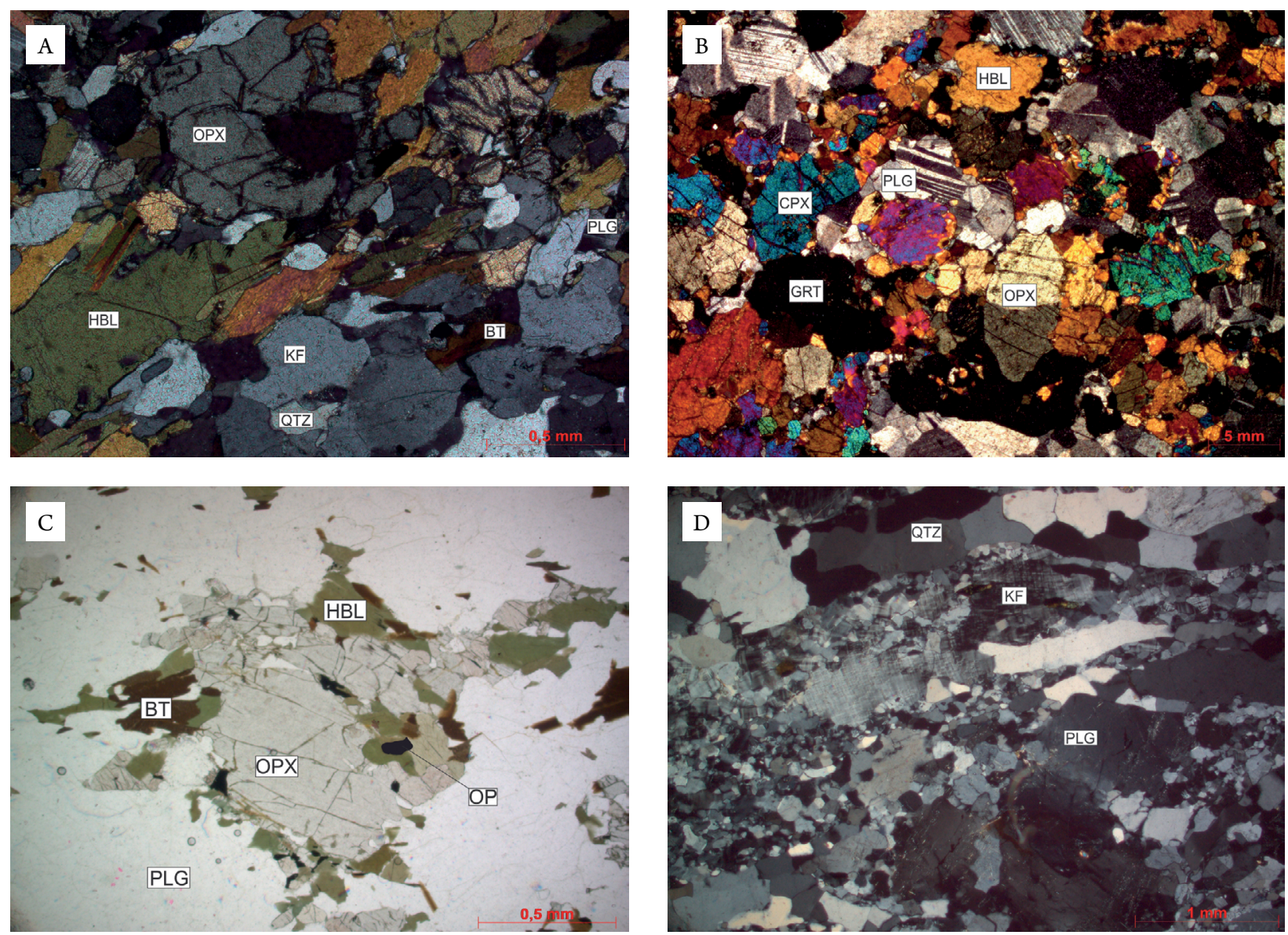

OPX: hyperstene; CPX: diopside; QTZ: quartz; PLG: plagioclase; KF: k-feldspar; HBL: hornblende; BT: biotite; OP: opaque minerals.

Figure 3. Petrographic features of the JFC orthogranulites. (A) mineralogy and granoblastic texture in the charnoenderbite; (B) mineralogy and granoblastic texture in the mafic granulite; (C) grano-porphyroblastic texture in the charno-enderbite, with opx partially substituted by biotite and hornblende; (D) mylonitic texture in a charnockite type with quartz ribbons and feldspar porphyroclasts.

Few samples display CIPW normative nepheline and absence of normative orthopyroxene (Tab. 2), suggesting their affinity with alkaline basalts. The other samples plot in the sub-alkaline field and contain hypersthene and olivine (Tab. 2), therefore classified as olivine tholeiites.

Alkaline samples occur as mafic bodies in the outcrop, with sharp boundaries with the sic rocks. These rocks are nominated here as BA group, showing high $(>2.2 \%) \mathrm{TiO}_{2}$ (Peate et al. 1992, Bellieni et al. 1984), enrichment in light rare earth elements (LREE) and conspicuously negative Eu anomaly (Fig. 5A). The tholeiitic rocks display low $\mathrm{TiO}_{2}(<2.2 \%)$ and are heterogeneous in chemical composition. Based on their REE signatures, they were subdivided into three groups, as follows: 1) The first tholeiitic group ( $\mathrm{TH} 1$ ), with three samples (blue symbols), shows minor LREE enrichment, less prominent negative Eu anomalies and flat heavy rare earth elements (HREE) distribution when compared with the alkaline group (Fig. 5B). Rocks of this group occur as mafic bands/ enclaves associated to felsic rocks;

2) The second tholeiitic group ( $\mathrm{TH} 2$ ), also represented by three samples (green symbols), displays flatter REE distribution patterns, with subtle LREE enrichment and absence of Eu anomalies (Fig. 5C);

3) The third tholeiitic group (TH3) has the lowest total REE content and displays LREE depletion and a completely flat
REE pattern. Two samples only present these characteristics (Fig. 5D).

Both $\mathrm{TH} 2$ and $\mathrm{TH} 3$ groups occur as mafic bodies in the outcrop, not always associated with felsic rocks. They also contrast with the TH1 group by their less evolved characteristics and REE distribution patterns, which are compatible respectively with E- and N-MORB basalts, highlighted by La/Sm normalized ratios higher and lower than 1 (Fig. 5D).

Tectonic discrimination diagrams (Fig. 6) corroborate the proposed subdivision, with the BA group plotting in the intraplate fields (Figs. 6A and 6B) or continental rift field (Fig. 6C). The tholeiitic groups plot on plate margin field (Fig. 6A), with the $\mathrm{TH} 1$ group related to convergent plate margin (Island Arc Tholeiite) and $\mathrm{TH} 2$ and $\mathrm{TH} 3$ groups, suggestive of extensional tectonic settings (MORB Figs. 6B and 6C).

\section{Felsic granulites}

The felsic rocks of the JFC show predominantly granodioritic compositions, with minor diorites and granites (Fig. 7A - Cox et al. 1979). They display calc-alkaline subalkaline signatures (Figs. 7B and 7C - Irvine \& Baragar 1971, Peccerillo \& Taylor 1976) with metaluminous character according to their Shand index (Fig. 7D — Shand 1943). Only two 

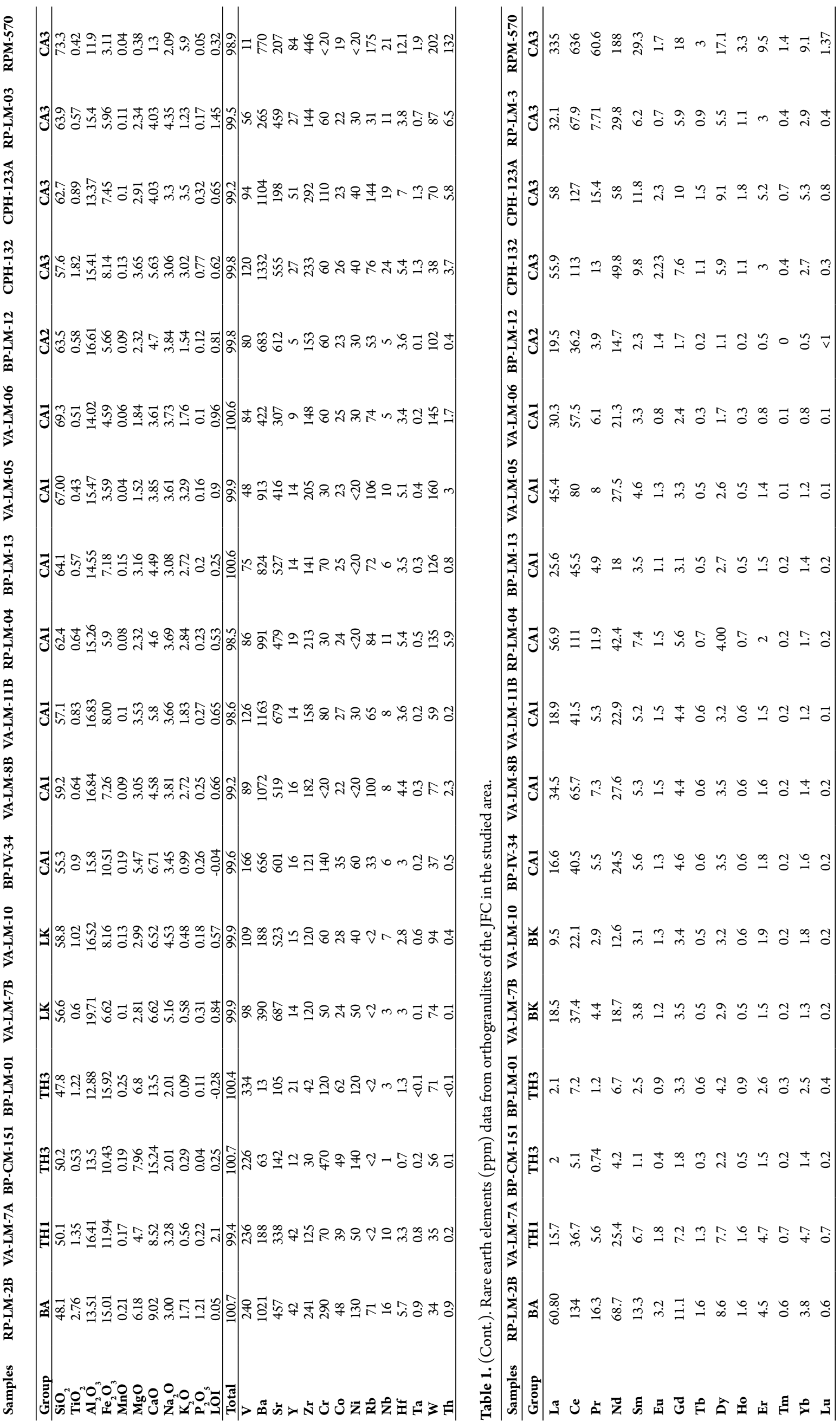
samples (RPM-344 and BP-CM 148) show alkaline character, given by their high alkalis (Fig. 7A) and other LILE contents.

Using the same approach based on REE chondrite-normalized signatures, the sub-alkaline samples were tentatively subdivided into four groups (Fig. 8):

- Low-Kcalc-alkaline rocks (LKgroup — black symbols) are represented by three dioritic enderbite samples. They show less fractionated REE pattern, with $(\mathrm{La} / \mathrm{Yb})_{N}$ ranging between 1.8 and 9.5 and varied $\mathrm{Eu}$ anomalies (Fig. 8A);

- CA1 calc-alkaline group (blue symbols) presents dioritic to granodioritic compositions, and enrichment in LREE and flat HREE patterns (Fig. 8B). This group show $(\mathrm{La} / \mathrm{Yb})_{\mathrm{N}}$ in a range between 6.9 and 25.5;

- CA2 calc-alkaline group (green symbols) is predominantly consisted of granitic rocks. They have characteristically positive Eu anomalies and more depleted HREE patterns (Fig. 8C). This group presents a more fractionated REE pattern marked by $(\mathrm{La} / \mathrm{Yb})_{\mathrm{N}}$ in a range between 20.6 and 49.6;

- CA3 calc-alkaline group (red symbols) has a more expanded composition, with dioritic to granitic rocks, more enriched in total REE (99.7 to 1,314) with less fractionated REE patterns $(\mathrm{La} / \mathrm{Yb})_{\mathrm{N}}=6.5$ to 26.6$)$ and prominent negative Eu anomalies (Fig. 8D).

Most samples present magnesian characteristics, except the more evolved rocks of CA2 and CA 3 groups, which are ferroan (Fig. 9A - Frost et al. 2001). CA1 and LK groups are calcic to calcic-alkalic, while $\mathrm{CA} 2$ and $\mathrm{CA} 3$ groups are calc-alkalic to alkali-calcic (Fig. 9B — Frost et al. 2001). Joining these characteristics, the CA1 and LK groups plot in the magmatic arc field, while the CA2 and CA3 show

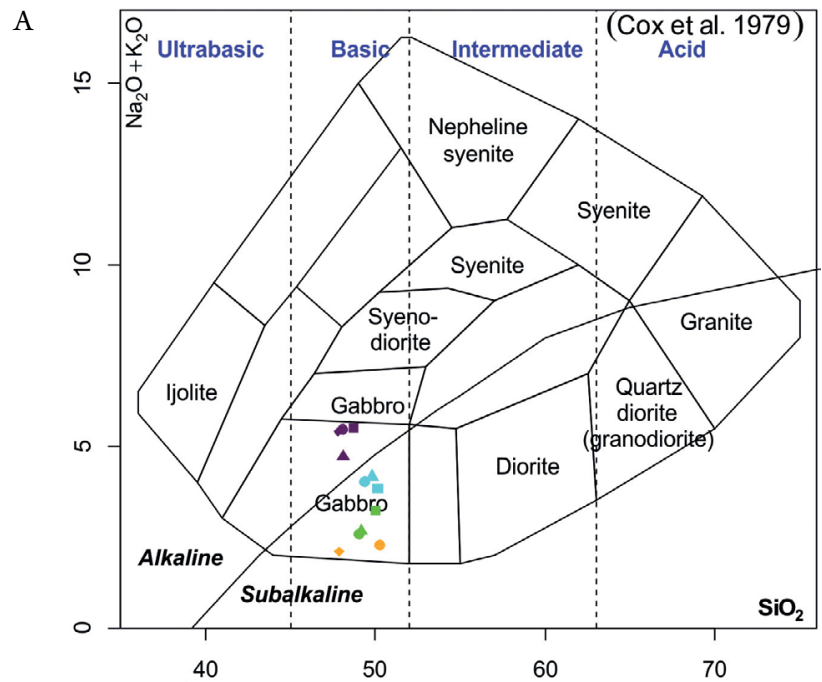

Symbols

VAL-M-503A

VA-LM-07A

VAL-M-503

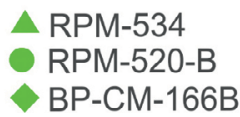

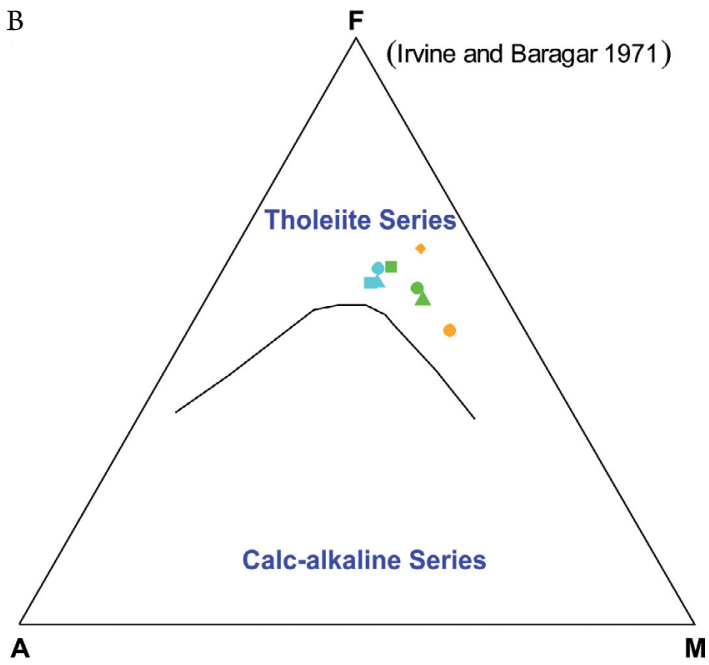

Labels by groups

TH1

$\mathrm{TH} 2$ TH3 BA

Figure 4. Geochemical diagrams of mafic granulites. (A) TAS diagram (Cox et al. 1979) classifying the samples accordingly its protholiths and magmatic series; (B) Classification of sub-alkaline samples into tholeiitic or calc-alkaline sub-series through AFM diagram (Irvine \& Baragar 1971).

Table 2. Normative minerals for the analyzed basic orthogranulites of the JFC.

\begin{tabular}{lcccccccccccc}
\hline Samples & Or & Ab & An & Ne & Di & Hy & Ol & Il & Ap & Sum & Classification & Group \\
\hline CJE-44-11 & 8.27 & 30.0 & 11.3 & 2.54 & 20.60 & 0.00 & 17.18 & 6.65 & 1.73 & 98.27 & alkalii basalt & BA \\
RP-LM-02B & 10.11 & 25.4 & 18.3 & 0.00 & 15.52 & 1.02 & 22.29 & 5.26 & 2.87 & 100.80 & olivine tholeiite & BA \\
CJE-44-3 & 8.27 & 28.8 & 12.6 & 2.71 & 20.88 & 0.00 & 16.43 & 6.65 & 1.66 & 98.01 & alkalii basalt & BA \\
NSA-5-9D & 8.27 & 34.5 & 12.7 & 0.08 & 15.12 & 0.00 & 19.30 & 6.27 & 1.37 & 97.62 & alkalii basalt & BA \\
VAL-M-503 & 4.91 & 27.1 & 19.7 & 0.00 & 20.16 & 6.19 & 16.29 & 3.42 & 0.55 & 98.33 & olivine tholeiite & TH1 \\
VAL-M-503A & 5.08 & 27.9 & 20.3 & 0.00 & 20.41 & 5.45 & 15.45 & 3.42 & 0.57 & 98.59 & olivine tholeiite & TH1 \\
VA-LM-07A & 3.31 & 27.8 & 28.4 & 0.00 & 10.47 & 17.98 & 6.30 & 2.58 & 0.52 & 97.32 & olivine tholeiite & TH1 \\
RPM-520B & 1.12 & 20.3 & 29.6 & 0.00 & 22.72 & 13.38 & 8.10 & 2.85 & 0.26 & 98.34 & olivine tholeiite & TH2 \\
RPM-534 & 0.95 & 21.2 & 28.1 & 0.00 & 24.62 & 10.66 & 10.03 & 2.66 & 0.28 & 98.50 & olivine tholeiite & TH2 \\
BP-CM-166B & 1.95 & 24.5 & 24.8 & 0.00 & 20.07 & 16.50 & 7.25 & 3.42 & 0.55 & 99.02 & olivine tholeiite & TH2 \\
BP-CM-151 & 1.71 & 16.9 & 27.0 & 0.06 & 39.89 & 0.00 & 13.79 & 1.01 & 0.10 & 100.49 & alkalii basalt & TH3 \\
BP-LM-01 & 0.53 & 17.0 & 25.9 & 0.00 & 34.07 & 0.70 & 19.94 & 2.32 & 0.26 & 100.69 & olivine tholeiite & TH3 \\
\hline
\end{tabular}


signatures of more evolved arc rocks to syn-collisional granitoids (Fig. 9C - Pearce et al. 1984).

\section{Sm-Nd and Sr-Srisotopes}

The measured and calculated isotope ratios, along with parameters such as $f_{\mathrm{Sm}} /{ }_{\mathrm{Nd}}, \varepsilon \mathrm{Nd}_{(\mathrm{t})}$ and $\mathrm{T}_{\mathrm{DM}}$ and $\mathrm{T}_{\mathrm{CHUR}}$ model

A

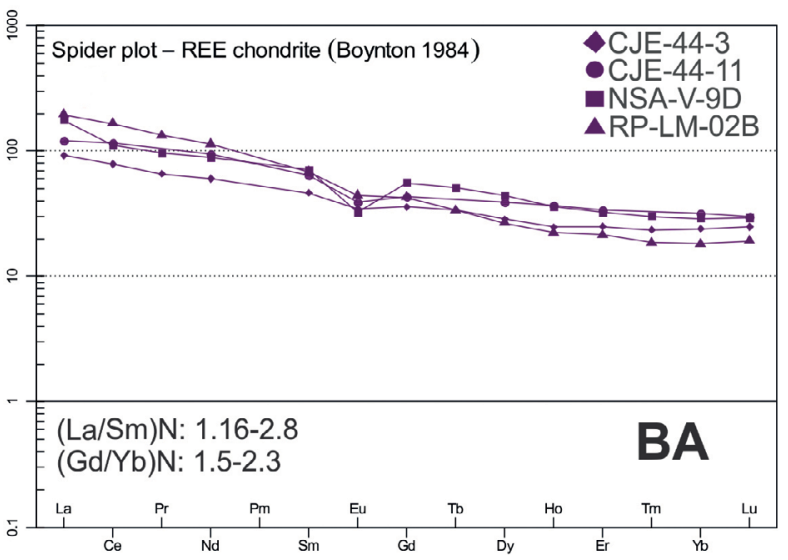

$\mathrm{C}$

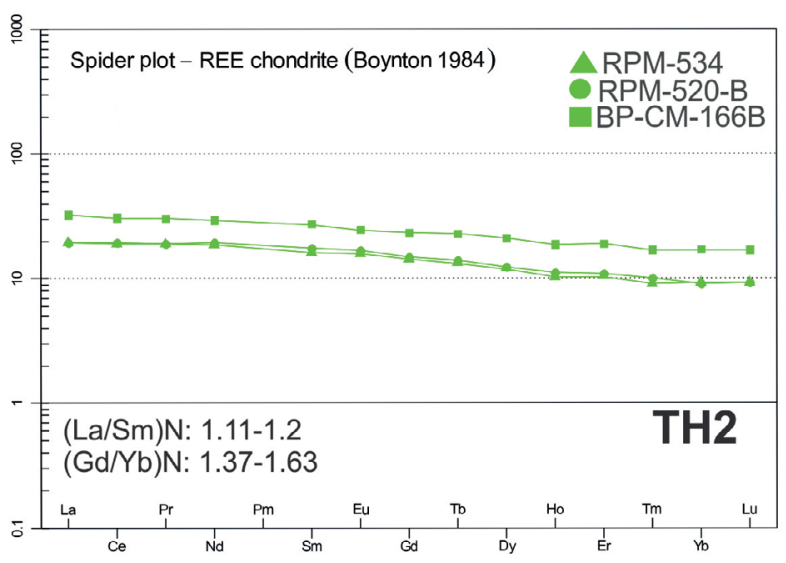

ages are shown in Table 3. Fractionation factors $\left(f_{\mathrm{Sm} / \mathrm{Nd}}\right)$ of the samples vary between -0.03 and -0.67 . Few samples yielded ${ }^{147} \mathrm{Sm} /{ }^{143} \mathrm{Nd}$ values above 0.17 and very low $f_{\mathrm{Sm} / \mathrm{Nd}}$ ratios between -0.03 and -0.12 , suggesting isotopic evolutions very similar to that of the Chondritic Uniform Reservoir (CHUR) (DePaolo 1988). In these cases, their $T_{C H U R}$ model ages were calculated.
B

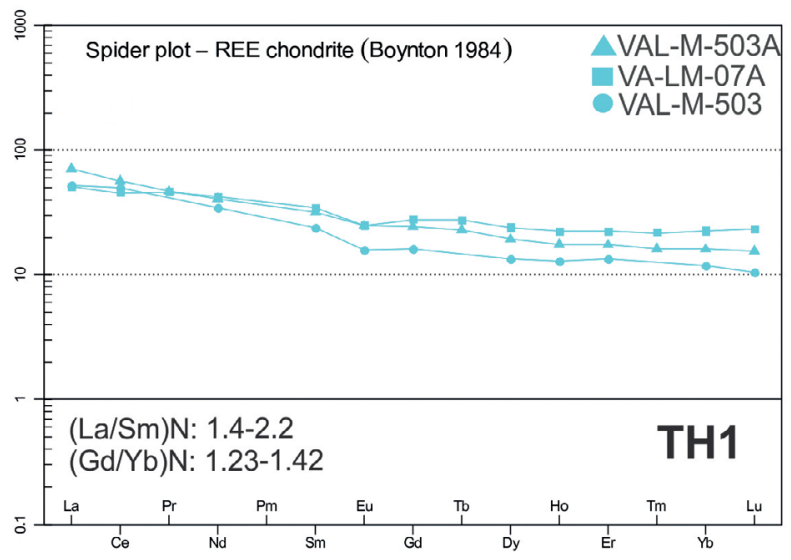

$\mathrm{D}$

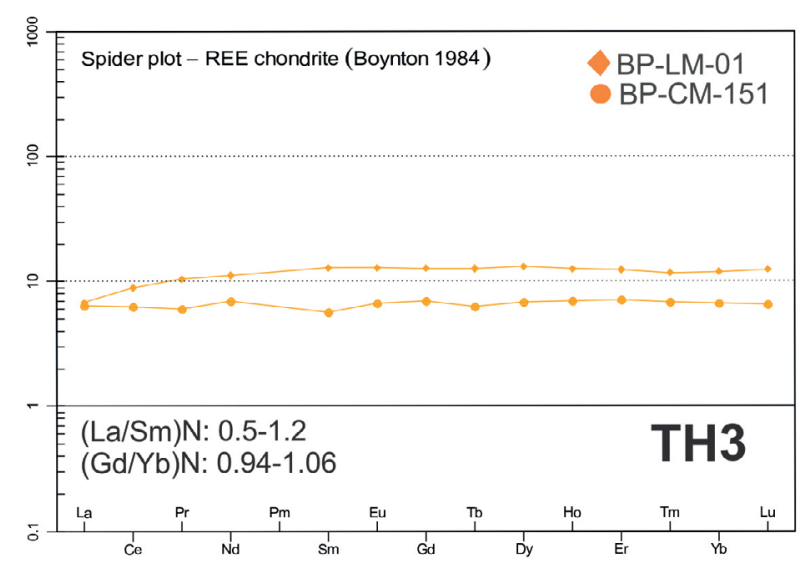

Figure 5. REE's chondrite normalized spidergram (Boynton 1984) of mafic granulites from study area. (A) BA group; (B) TH1 group; (C) TH2 group; (D) TH3 group.

A

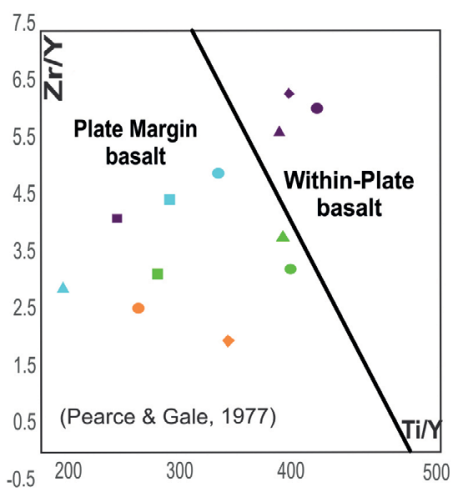

B

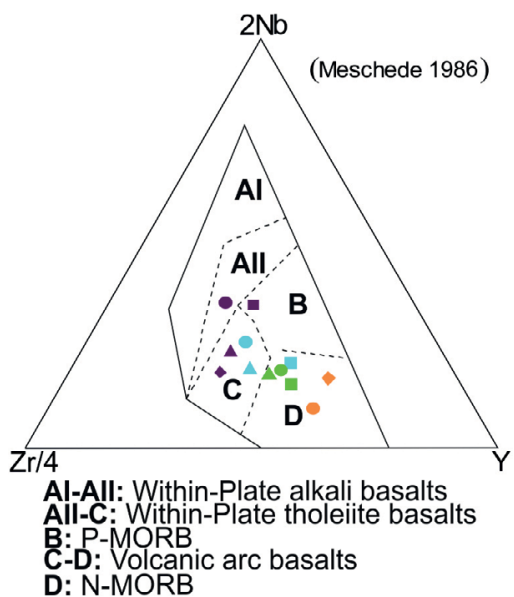

C

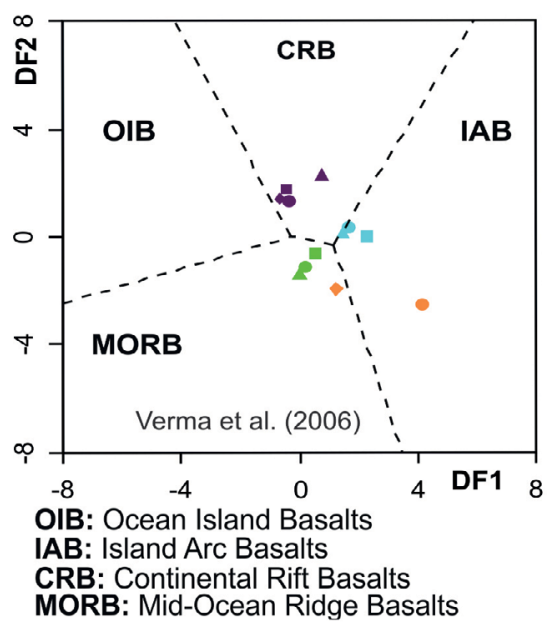

Figure 6. Geotectonic settings of studied mafic granulites. (A) Classification of basalts accordingly its position on the tectonic plate (Pearce \& Gale 1977); (B) tectonic classification focusing on different tectonic setting for tholeiitic basalts (Meschede et al. 1986); (C) Tectonic classification for samples with basic or ultrabasic compositions (Verma et al. 2006). Symbols as in the Figure 4. 
Felsic rocks predominantly yielded Sm-Nd $\mathrm{T}_{\mathrm{DM}}$ ages between 2.48 and $2.03 \mathrm{Ga}$ (Fig. 10) with weakly positive or slightly negative $\varepsilon \mathrm{Nd}_{(\mathrm{t})}$ values $(-3.94$ to +0.08$)$. Few felsic samples yielded $\mathrm{T}_{\mathrm{DM}}$ ages from 2.75 to $2.58 \mathrm{Ga}$. These rocks yield significantly negative $\varepsilon \mathrm{Nd}_{(t)}$ values (-6.91 to -5.5$)$. We note that two felsic granulite samples (VA-LM-06 and CPH-132) yielded younger Orosirian Sm-Nd T ${ }_{\mathrm{DM}}$ model ages (1.93 and $1.90 \mathrm{Ga}$ ), as shown in Figure 10.

The basic rocks have varied Sm-Nd $\mathrm{T}_{\mathrm{DM}}$ ages (Fig. 10), according to their geochemical signatures: The $\mathrm{TH} 1$ group, with IAT signatures and the BA group with intraplate signatures exhibit normal ${ }^{147} \mathrm{Sm} /{ }^{143} \mathrm{Nd}$ and $f \mathrm{Sm} / \mathrm{Nd}$ values. The $\mathrm{TH} 1$ group yielded roughly similar $\mathrm{T}_{\mathrm{DM}}$ ages of 2.35-2.27 Ga with weakly negative to positive $\varepsilon \mathrm{Nd}_{(\mathrm{t})}$ values $(-0.88$ to +0.08$)$. In contrast, the $\mathrm{BA}$ group yielded $\mathrm{T}_{\mathrm{DM}}$ model ages between 2.52-2.21 Ga, with higher negative $\varepsilon \mathrm{Nd}_{(\mathrm{t})}$ values (-7.32 and -1.92). The TH2 and TH3 groups, with respectively $\mathrm{E}-$ and $\mathrm{N}-\mathrm{MORB}$ signatures, show no $\mathrm{Sm} / \mathrm{Nd}$ fractionation relative to the CHUR, presenting positive $\varepsilon \mathrm{Nd}_{(\mathrm{t})}$ values $(+0.33$ to +3.83$)$.

For the calculation of initial isotopic parameters, such as $\varepsilon \mathrm{Nd}_{(\mathrm{t})}$ and ${ }^{87} \mathrm{Sr} /{ }^{86} \mathrm{Sr}_{(\mathrm{i})}$ values, the available U-Pb ages reported in the literature for the same geochemical groups (see Suppl. Tab. A1) were used, including ages previously obtained within the study area (Machado et al. 1996, Heilbron et al. 2010).

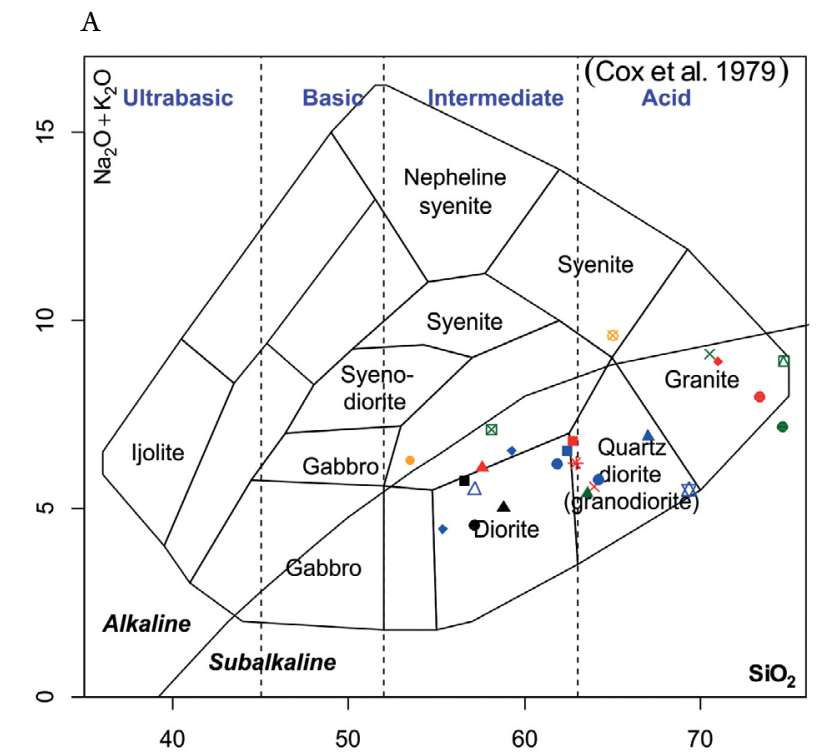

B

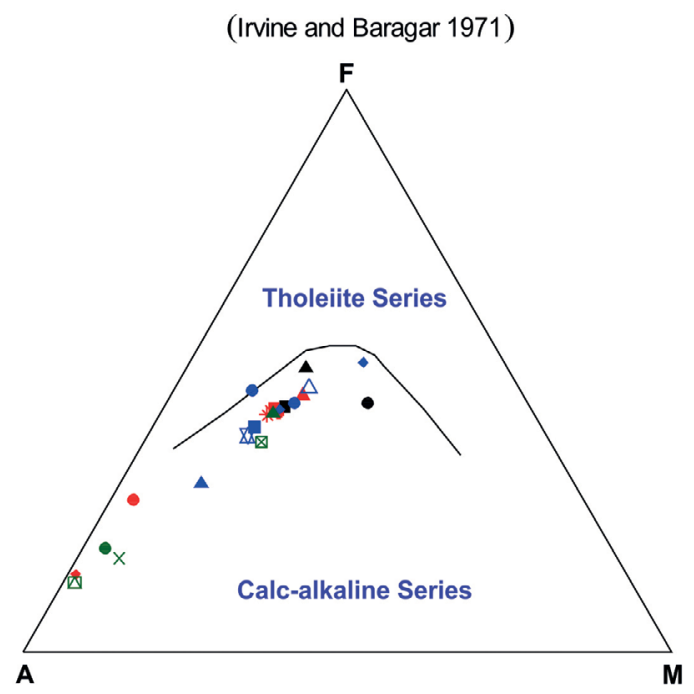

$\mathrm{C}$
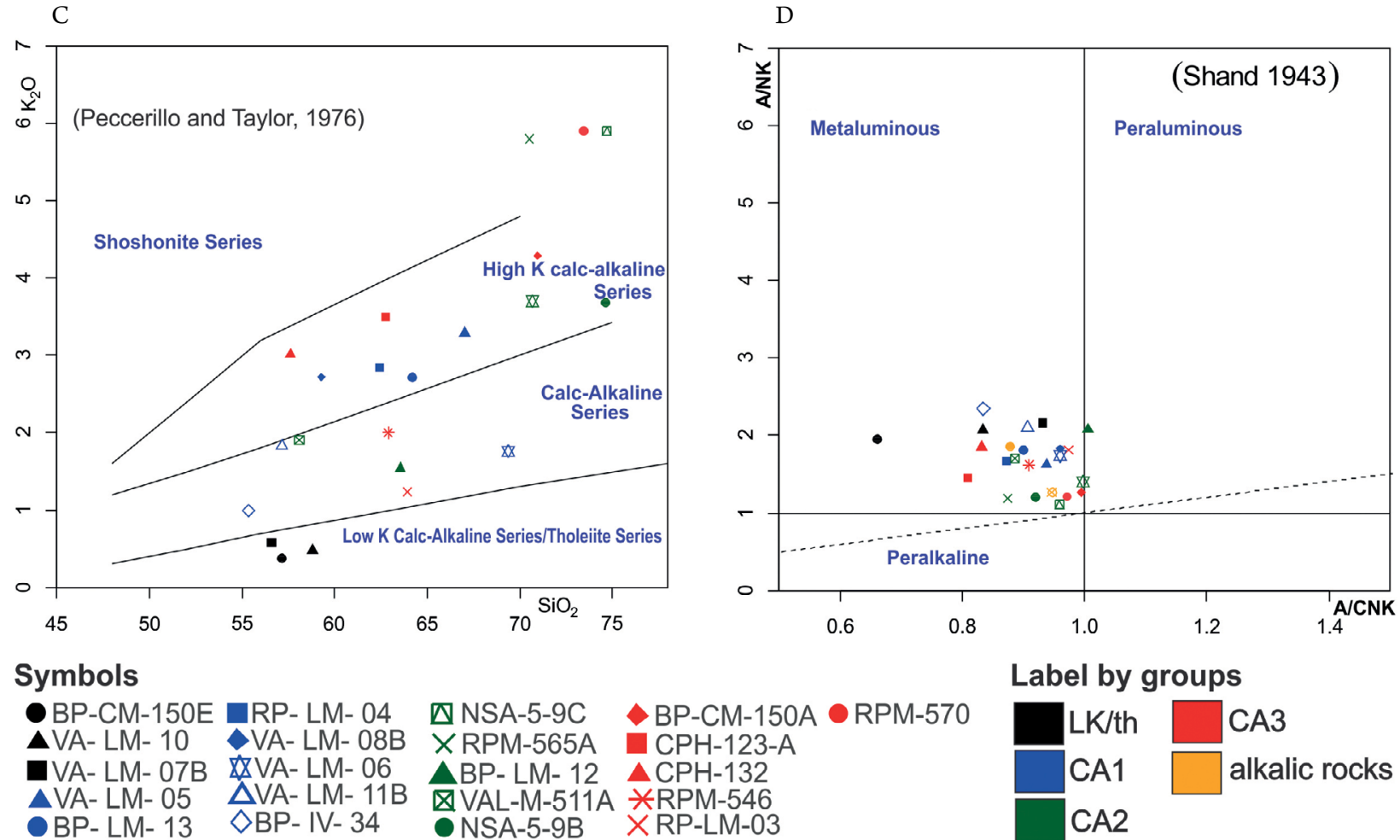

Symbols

BP-CM-150E

AVA- LM- 10

VA- LM- 07B

VA- LM- 05

BP- LM- 13

RP- LM- 04

$\triangle N S A-5-9 C$

VA- LM- 08B

$\times$ RPM-565A

BP- LM- 12

$\triangle V A-$ LM- 11B

凶VAL-M-511A

NSA-5-9B

Label by groups

Figure 7. Geochemical classification plots of studied felsic granulites. (A) Protholiths classification and magmatic series classification (Cox et al. 1979); (B) classification of sub-alkaline samples into tholeiitic or calc-alkaline sub-series through AFM diagram (Irvine \& Baragar 1971); (C) Classification of calc-alkaline rocks (Peccerillo \& Taylor 1976); (D) Alumina Saturation Index classification (Shand 1943). 
The $\mathrm{T}_{\mathrm{DM}}$ and geochemical signature obtained were used to decide which U-Pb crystallization age should be applied for the calculation of the $\mathrm{Sr}$ initial ratios and $\varepsilon \mathrm{Nd}(\mathrm{t})$. Selected ages were:

- $2.1 \mathrm{Ga}$ for calc-alkaline silicic arc rocks;

- $1.76 \mathrm{Ga}$ for alkaline intra-plate mafic rocks;

- 766 Ma for MORB tholeiitic mafic rocks (see Suppl. Tab. A1).

A

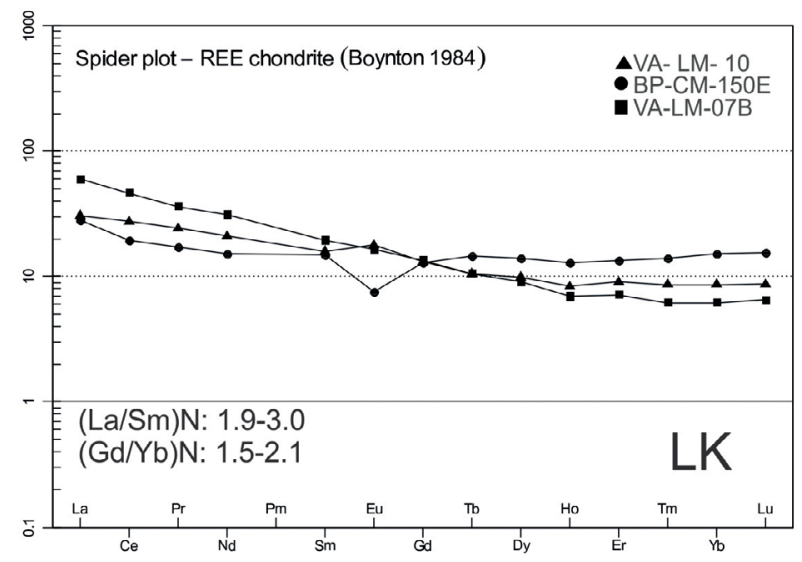

C

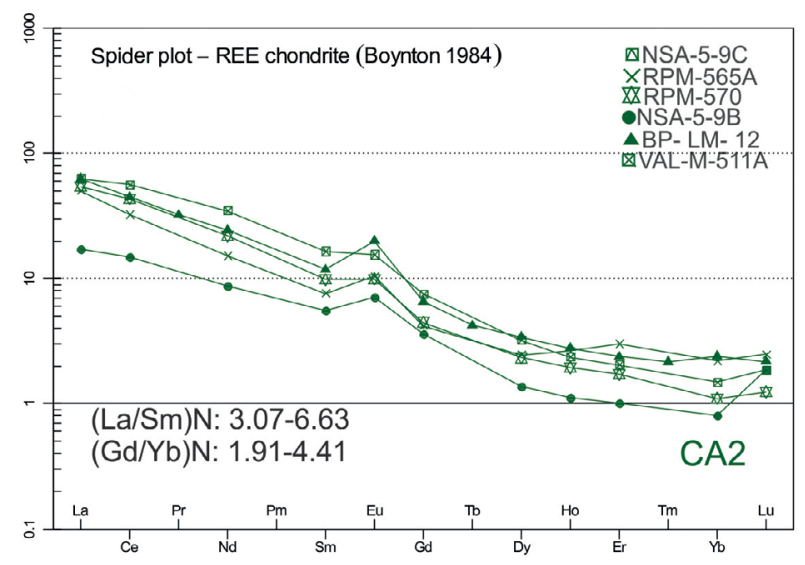

The basic, intermediate and acid granulites yielded initial ${ }^{87} \mathrm{Sr} /{ }^{86} \mathrm{Sr}_{(\mathrm{i})}$ ratios, respectively of $0.700-0.702,0.703-0.704$ and 0.710-0.715. Two samples (CPH-123A and RPM-570) yielded anomalous initial ratios of 0.693 and 0.751 . The anomalously low value may indicate disequilibrium in the $\mathrm{Rb}-\mathrm{Sr}$ systematic, as expected for granulite facies rocks in the presence

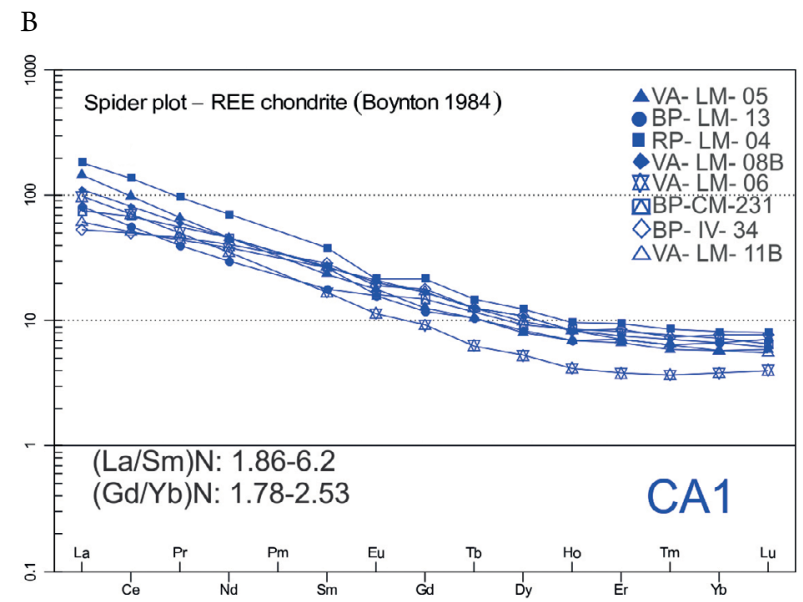

$\mathrm{D}$

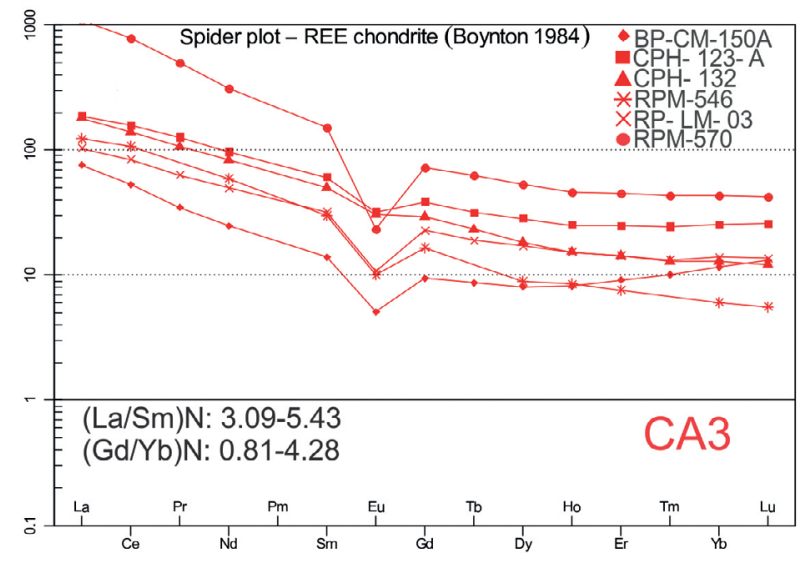

Figure 8. REE's chondrite normalized spidergram (Boynton 1984) of felsic granulites within study area. (A) LK group; (B) CA1 group; (C) CA2 group; (D) CA3 group.

A

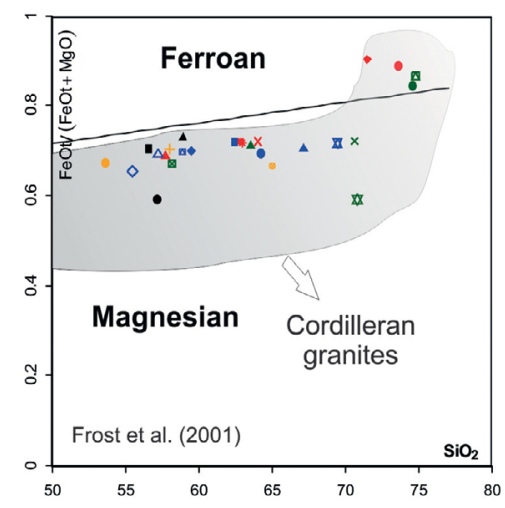

Label by groups
B

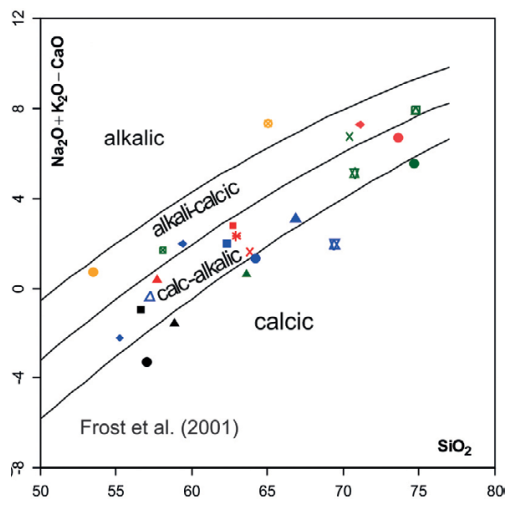

CA2
C

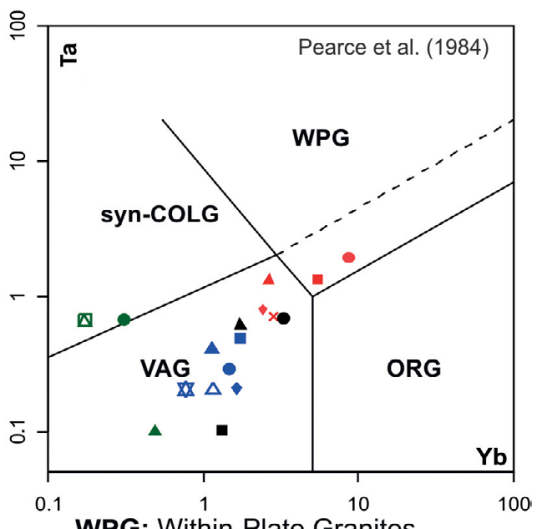

WPG: Within-Plate Granites syn-COLG: Syn-Collisional Granites VAG: Volcanic Arc Granites ORG: Ocean Ridge Granites

Figure 9. Geotectonic plots of studied felsic granulites. (A) Classification accordingly Fe Number and $\mathrm{SiO}_{2}$ (Frost et al. 2001); (B) classification accordingly Modified Alkali-Lime Index (MALI) and Aluminium Saturation Index (ASI) (Frost et al. 2001); (C) tectonic classification for granitoids (Pearce et al. 1984). 
of melting. The very high ${ }^{87} \mathrm{Sr} /{ }^{86} \mathrm{Sr}_{(\mathrm{i})}$ value is consistent with crustal contamination in the upper crust. Therefore, they will not be considered hereafter.

Figure 11 shows the correlation of the $\mathrm{Nd}$ and $\mathrm{Sr}$ signatures for the felsic granulites studied, displaying arc-related affinity, modelled for $2.1 \mathrm{Ga}$. Most samples plot in the lower crust field (Faure 1986). Basic rocks samples and diorites of the TH1 and LK groups, respectively, are possibly derived from a predominant juvenile component due to its greater similarity to the Bulk Earth composition (Allègre et al. 1995).

\section{DISCUSSION}

\section{Petrogenetic parameters, sources and metamorphism}

Felsic granulite samples show similar mineralogy, with progressive increase in quartz, K-feldspar in the granitic samples (Fig. 12). In particular the CA1 and CA3 groups display more expanded compositions, from diorites to granites, while the LK and CA2 groups show more restrict compositions, respectively with diorites and granites. The LK group may be considered as evolved members of the TH1 group (Fig. 13), since both share a more primitive IAT signature with similar REE patterns. The felsic CA2 group displays characteristically positive Eu anomalies, explained by plagioclase accumulation. Furthermore, this group has slightly depleted HREE patterns, possibly indicating either the presence of residual garnet in the source rocks, as suggested by Heilbron et al. (1998) or early amphibole fractionation in the source rock (Dessimoz et al. 2012). The CA1, LK and TH1 groups have slightly negative to absent $\mathrm{Eu}$ anomalies that are suggestive of either an oxidizing signature of magma and/or plagioclase-rich mantle sources (Wilson 1989). The LREE enrichment of the CA1 group may be attributed to the enrichment of mantle sources, a common feature in modern oceanic arcs (Smithies et al. 2004, Sun \& Nesbitt 1978, Cameron et al. 1979, Crawford et al. 1989). The same effect of LREE enrichment in rocks of the BA group may be explained by small degrees of partial melting of their sources, as expected for alkali basalts (Cheng et al. 1993). The CA3 and BA groups have a strong negative Eu anomaly, possibly due to low oxygen fugacity and temperature of its magma formation (Hanson 1980). The very high LREE enrichment noticed in the REE spidergram (Fig. 8) of sample RPM-570, when compared to the other samples, may be attributed to the presence of allanite. Depleted LREE signature of the $\mathrm{TH} 3$ group suggests a derivation from a LREE depleted garnet-free source and/or a high degree of partial melting in the source.

Considering the petrogenetic parameters, we postulate that felsic granulites from the LK group, mafic granulites of the $\mathrm{TH} 1$ group and most samples of the $\mathrm{CA} 1$ group represent juvenile Paleoproterozoic protholiths, due to their weakly negative to slightly positive $\varepsilon \mathrm{Nd}(\mathrm{t})$ values $(-3.94$ to +0.08$)$ and low ${ }^{87} \mathrm{Sr} /{ }^{86} \mathrm{Sr}_{(\mathrm{i})}$ values ( 0.701 to 0.702 - mean variation). Negative $\varepsilon N d(t)$ values $(-7.32$ e -1.92) of the intraplate basic rocks of the BA group constitute isotopic evidence of crustal contamination. Positive $\varepsilon \mathrm{Nd}(\mathrm{t})$ values of the $\mathrm{TH} 2$ and $\mathrm{TH} 3$ groups $(+0.33$ to +3.83$)$ suggest juvenile mantle sources. ${ }^{87} \mathrm{Sr} /{ }^{86} \mathrm{Sr}_{(\mathrm{i})}$ values of the less evolved $\mathrm{TH} 2$ and $\mathrm{TH} 3$ groups are close to those of the chondrite reservoir $\left({ }^{87} \mathrm{Sr} /{ }^{86} \mathrm{Sr}_{(\mathrm{i}) \mathrm{CHUR}}=0.699\right)$, suggesting isotopic affinity with a depleted source. The CA2 group has higher ${ }^{87} \mathrm{Sr} /{ }^{86} \mathrm{Sr}_{(\mathrm{i})}$ values $(0.705-0.722), \mathrm{T}_{\mathrm{DM}}$ model ages $(2.31$ to $2.03 \mathrm{Ga})$ and weakly negative to positive $\varepsilon \mathrm{Nd}_{(\mathrm{t})}$ values $(-2.91$ to +1.65$)$, that could have been derived from an enriched continental source.

All geochemical groups, with different tectonic signatures and varied $\mathrm{T}_{\mathrm{DM}}$ model ages, show similar granulite facies paragenesis. For instance, the granulite rocks of the JFC display $o p x+p l g+q t z \pm c p x \pm h b l \pm k f+z r+i l+a p \pm a l n$, or grt + $\mathrm{cpx}+\mathrm{qtz}+\mathrm{plg} \pm \mathrm{opx} \pm \mathrm{hbl}+\mathrm{il}+\mathrm{mgt} \pm \mathrm{zr}$ assemblages, suggestive for progressive metamorphism with intermediate to high pressures. Mylonitic rocks show retrogressive paragenesis $(\mathrm{hbl}+\mathrm{bt})$ pointing to the upper amphibolite facies conditions. These observations are consistent with published works of JFC rocks (Duarte et al. 1997, Heilbron et al. 1998). Together, these petrographic evidences and the geochronological background, reinforce that the study area was overprinted by the Brasiliano regional granulite facies overprint, in the context of the Ribeira belt (see Suppl. Tab. A1).

\section{Regional correlations and proposed geochronologic evolution}

New geochemical and isotopic data allow correlation with other published data for the JFC. Figure 14 shows the regional distribution of new and compiled data for the JFC (Tab. 4).

The geochemical characteristics of the CA1 group are similar to the most widespread rocks of the JFC, highlighted by the medium-K calc-alkaline granulites (tonalites and diorites, characterized by LREE enrichment) described by most authors in the Central Segment of the Ribeira belt, as reported by Heilbron et al. (1998, 2010), Duarte et al. (1997) and Heilbron et al. (2013). Ages between ca. 2.2 and 2.07 Ga have been reported in the literature for similar rocks. On the other hand, the CA2 group, corresponds to the enderbitic granulite gneisses from Manhuaçu of Costa (1998), and to the high-K calc-alkaline suite of André et al. (2009) in the Três Rios region, with U-Pb ages of ca. 2.1 Ga (Fig. 14). Both associations are also characterized by lower HREE contents, positive Eu anomalies and $(\mathrm{La} / \mathrm{Yb})_{\mathrm{N}}$ ratios between 25 and 36 .

Most of the obtained Sm-Nd $\mathrm{T}_{\mathrm{DM}}$ model ages for the felsic granulites yielded values of ca. 2.3 to $2.5 \mathrm{Ga}$ with $\varepsilon \mathrm{Nd}_{(\mathrm{t})}$ values between -0.4 to -3.5 . These values are very similar to the data reported for the High-K calc-alkaline granulites of the Três Rios region (André et al. 2009) equivalent to the CA2 group, and for the enderbitic granulites of the Abre Campo-Manhuaçu region in Minas Gerais State (Fischel et al. 1998), equivalent to our CA1 group. Altogether, these $\mathrm{T}_{\mathrm{DM}}$ model ages between ca. 2.2 and $2.3 \mathrm{Ga}$ with slightly positive $\varepsilon \mathrm{Nd}(\mathrm{t})$ values reinforce our interpretation that the JFC is mostly represented by juvenile Paleoproterozoic arc related rocks. However, few felsic granulites yielded older $\mathrm{T}_{\mathrm{DM}}$ model ages of ca. 2.75 to $2.58 \mathrm{Ga}$, suggesting that some older material could have contributed to the formation of these rocks. Similar older Archean 


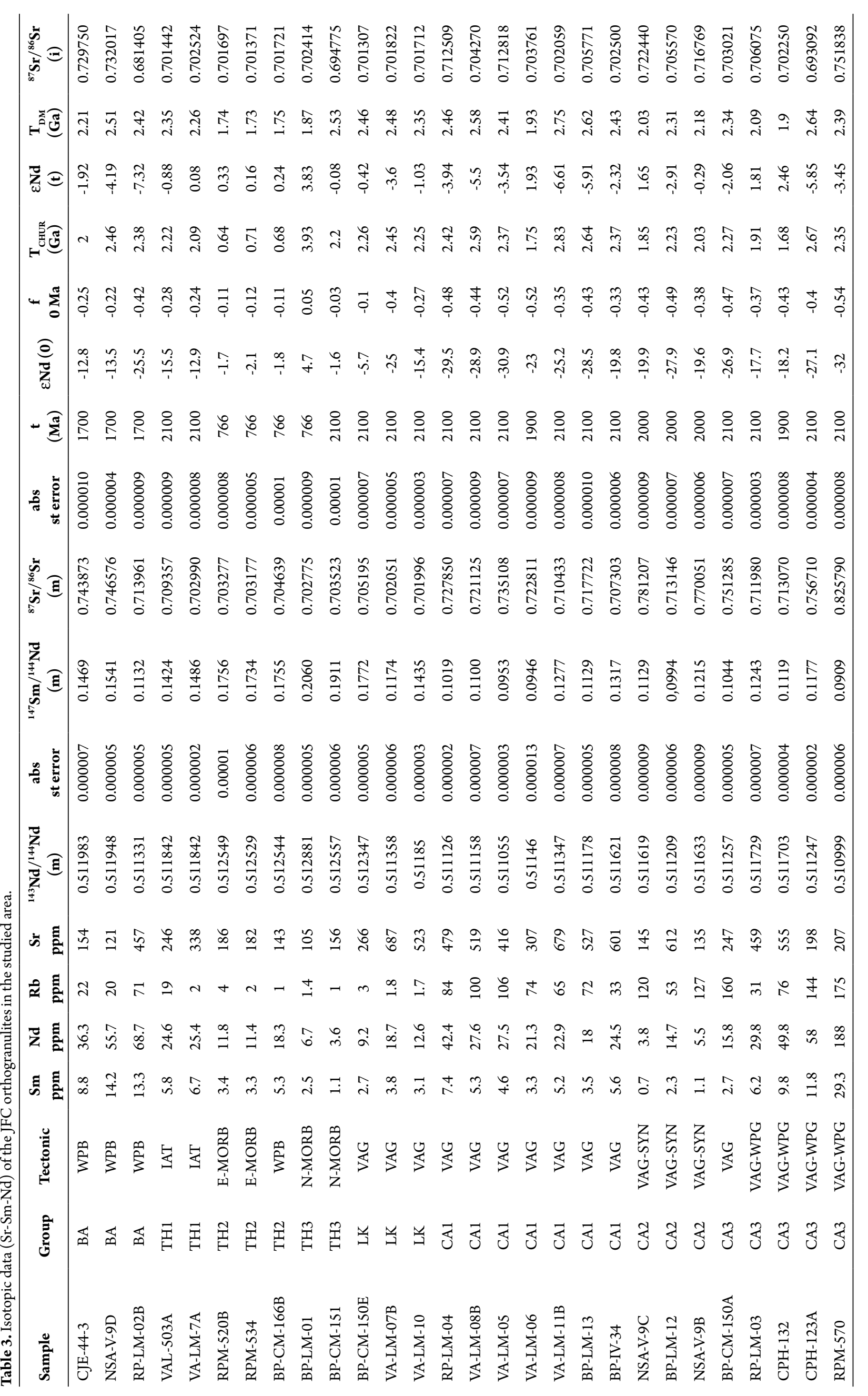


A
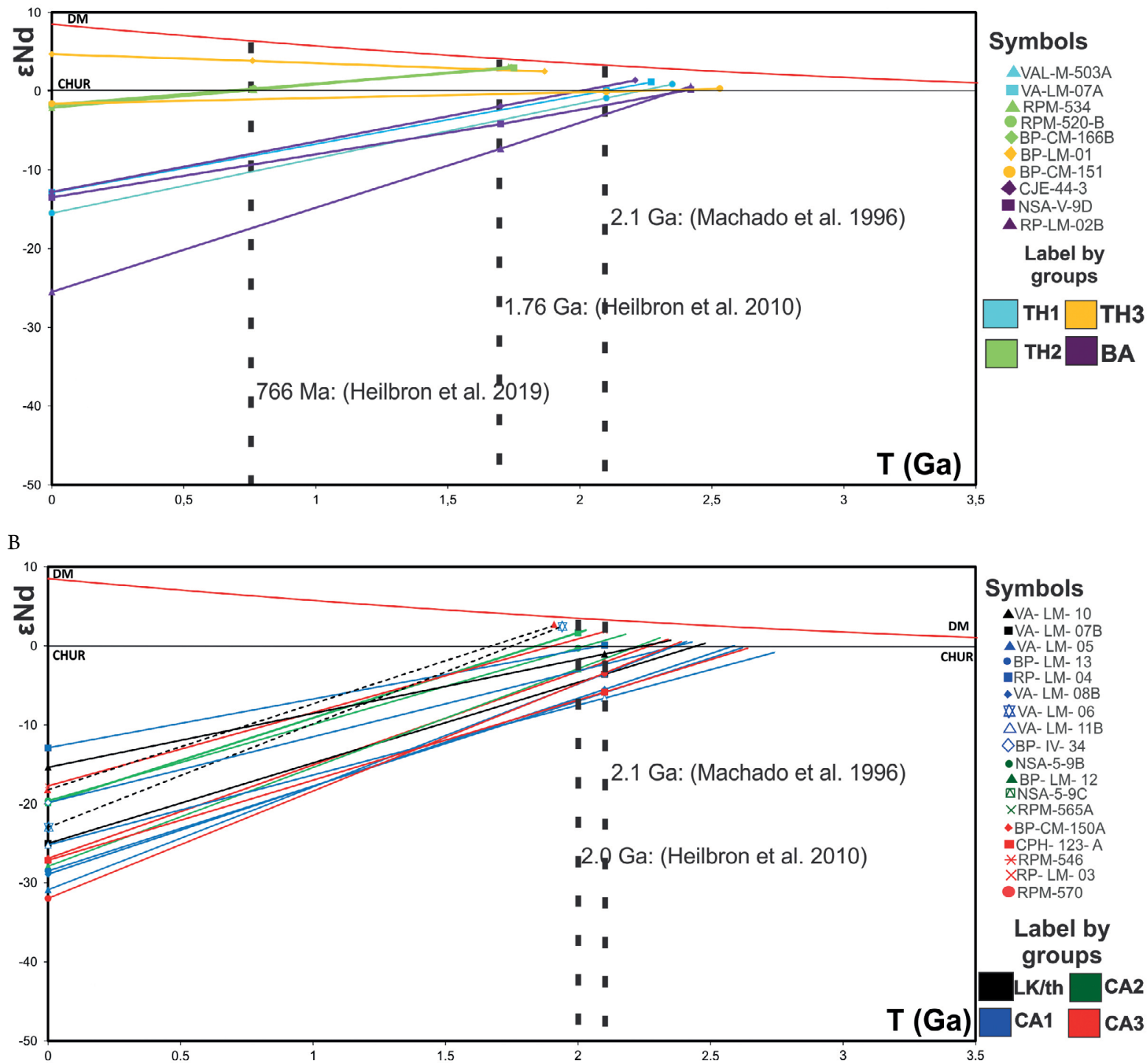

Figure 10. Nd evolution diagram ( $\varepsilon N d x$ Time) for the (A) basic and (B) felsic rocks of the JFC. Depleted Mantle data extracted from DePaolo (1981).

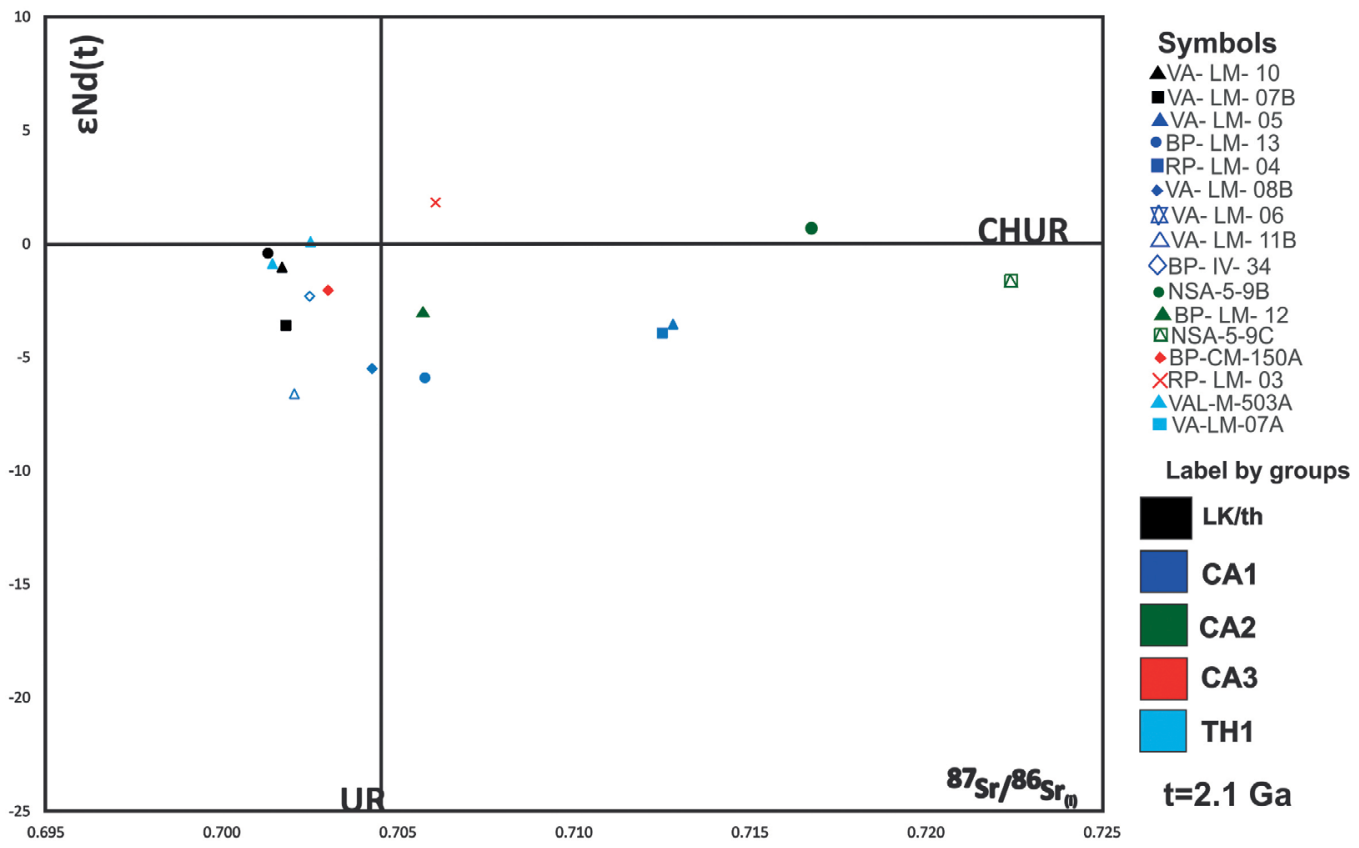

Figure 11. Nd-Sr correlation diagram of JFC arc rocks at 2.1 Ga. Uniform Reservoir data extracted from DePaolo (1988). 
model ages were described for the northern segment of the Ribeira (Silva et al. 2002, Kuribara et al. 2019, Fischel et al. 1998). On the other hand, few Orosirian $T_{D M}$ model ages of samples VA-LM-06 (CA1 group) and CPH-132 (CA3 group) do not show correlation with any previously published data for the JFC rocks. These samples present the youngest $T_{D M}$ model ages ofJFC, never reported before in the literature, and could represent a younger episode of felsic rocks generation within the complex.

The alkaline basic granulites of the study area, the BA group, with intraplate signatures, were previously detected in the study area with $\mathrm{U}-\mathrm{Pb}$ ages of ca. 1.7 to $1.6 \mathrm{Ga}, \mathrm{Sm}-\mathrm{Nd}$ $\mathrm{T}_{\mathrm{DM}}$ model ages of $2.14 \mathrm{Ga}$ and $\varepsilon \mathrm{Nd}$ values of -7.32 to -1.92 (Ragatky et al. 1999, Heilbron et al. 2010). These characteristics are suggestive for intraplate magmatism probably related to the development of Mesoproterozoic basins, such as the Espinhaço rift.

Basic granulitic rocks of the $\mathrm{TH} 3$ group show similarities with the High-Mg group of Duarte et al. (1997) for the Juiz de Fora region (Fig. 14). Both present N-MORB signatures and a wide span of $\mathrm{T}_{\mathrm{DM}}$ model ages (ca. $2.4 \mathrm{Ga}$ to $1.87 \mathrm{Ma}$ ).

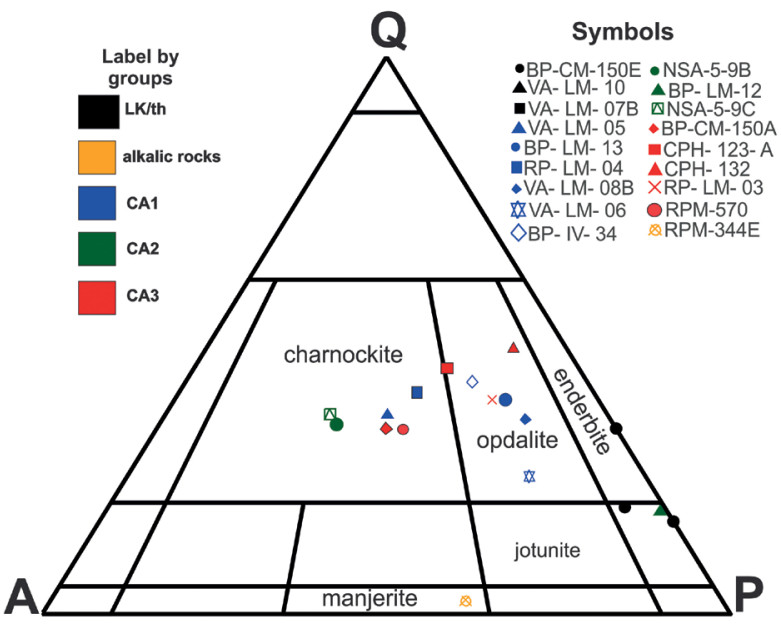

Figure 12. QAP diagram (Streckeisen 1974) for the felsic granulites with the adopted geochemical subdivision. See text for the discussions.

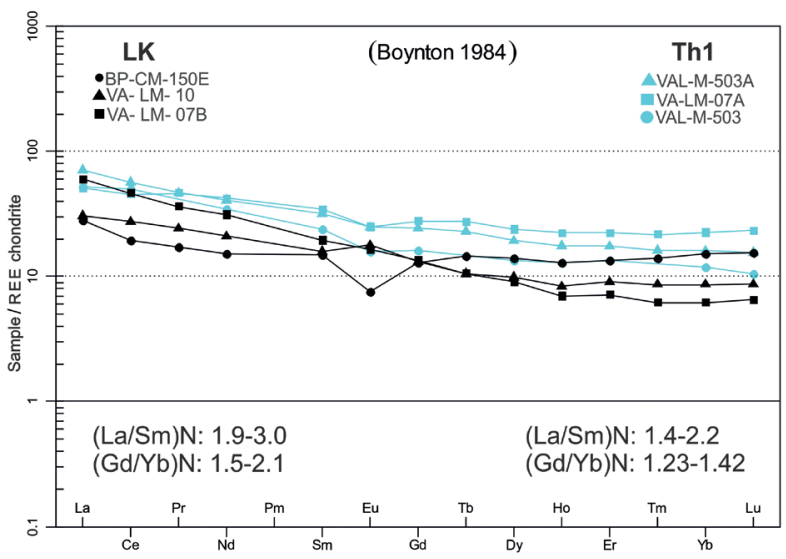

Figure 13. REE Comparison (Boynton 1984) between intermediate felsic rocks of the BK group with the basic rocks of the TH1 group.
These model ages results should be regarded with care, because of the very little evolved isotopic characteristics of these rocks.

On the other hand, tholeiitic rocks of the $\mathrm{TH} 2$ group in the study area are very similar to those described both in the Santo Antonio de Pádua region (Heilbron et al. 2013), and to the medium-Mg tholeiitic group in the Juiz de Fora region (Duarte et al. 1997). All these basic granulites display E-MORB like REE distribution patterns and present younger Mesoproterozoic $\mathrm{T}_{\mathrm{DM}}$ model ages (from 1.87 to 1.74 ), that speculatively could be related to development of the younger Meso- to Neoproterozoic basins, i.e., Carandaí (as proposed by Ribeiro et al.2013) and/or Andrelândia.

Previously available U-Pb data together with the Nd-Sr isotopic constraints for the JFC suggests the recognition of four tectono-magmatic events, unraveling the complexity of this basement association in the central portion of the Ribeira belt (Tab. 4, Fig. 15):

- The most common U-Pb crystallization ages of the felsic granulites span between ca. 2.2 to $2.07 \mathrm{Ga}$ with juvenile signatures are regarded as subduction related magmatism, probably evolving from an immature intra-oceanic magmatic arc to a more evolved setting. They are represented by the IAT and the alc-alkaline CA1 and CA2 groups. Part of the samples of the $\mathrm{CA1}$ group yielded older $\mathrm{T}_{\mathrm{DM}}$ model ages between 2.7 and $2.6 \mathrm{Ga}$, suggesting that some Archean material could have been involved in the generation of these rocks. Until now, only one occurrence of Archean granitoid rocks within the JFC was reported by Silva et al. (2002) in the vicinity of the city of Juiz de Fora (Fig. 15A). Rocks of the CA3 group, showing more evolved signatures, suggest that the older and more primitive arc-related rocks could have contributed to the generation of this geochemical group;

- Charnockitic rocks of the CA2 group belong to the High-K calcalkaline group and could have resulted from the melting of the previously formed arc-related rocks. The CA2 granitic group was probably generated during the collision of the Juiz de Fora arc with the São Francisco Paleocontinent between ca. 2.07 and $2.04 \mathrm{Ga}$, or either following the main collision episode, during later stages of the Rhyacian Orogeny (Fig. 15B, Tab. 4);

- One single c. $1.7 \mathrm{Ga}$ alkaline basic rock (high $\mathrm{TiO}_{2}$ and LREE content and negative Eu anomaly) with ca. 2.14 $\mathrm{T}_{\mathrm{DM}}$ model age is correlated with the Statherian extensional episode (Fig. 15C) that resulted in the development of the Espinhaço intraplate basin (Santos et al. 2015);

- The basic granulite rocks of the $\mathrm{TH} 2$ and $\mathrm{TH} 3$ groups, with younger $\mathrm{T}_{\mathrm{DM}}$ model ages could be related with the development of younger Meso-Neoproterozoic basins (Fig. 15C). More recently, one single intraplate basic body of ca. $766 \mathrm{Ma}$ (Heilbron et al. 2019) was interpreted as coeval with the development of the Andrelândia basin (Trouw et al.2000). Similar Cryogenian ages have been reported for metabasic rocks intercalated with the Macaúbas metasedimentary rocks in northern Araçuaí belt (Pedrosa-Soares \& Alkmim 2011);

- The tectonic evolution ofJFC ends with the superposition of the deformation and high-grade metamorphism related to the 
Brasiliano Orogeny between ca. 620 to $524 \mathrm{Ma}$ (see Suppl. Tab. A1) that resulted from docking of outboard terranes (Paraíba do Sul-Socorro and Oriental) onto the reworked passive margin of the SF paleocontinent, during the development of the Ribeira belt, as proposed by Tupinambá et al. (2000) and Heilbron et al. (2000, 2017). This superposition resulted in intense tectonic interdigitation and granulite facies metamorphism observed in all rocks of the studied area. Final exhumation of the orthogranulites was associated to intense mylonite fabric generation under retrogressive amphibolite facies conditions (Heilbron et al. 1998).

The envisaged tectonic evolution of the JFC in the study are is similar to previously proposed models (Heilbron et al.
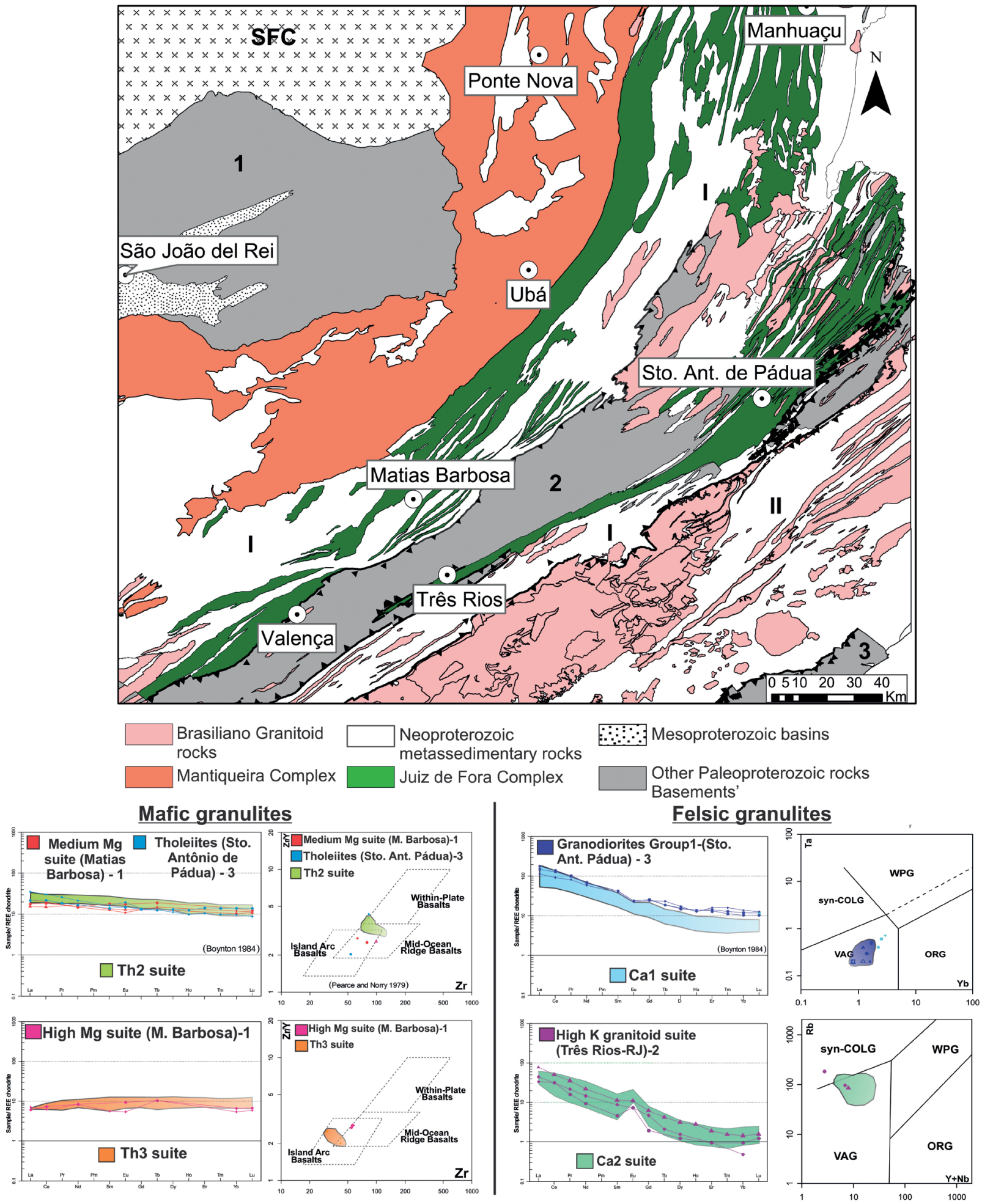

Figure 14. Tectonic Regional map with geochemical correlations of JFC between different regions of Minas Gerais and Rio de Janeiro. Paleoproterozoic basement (gray): (1) Mineiro Belt; (2) Paraíba do Sul Terrane of Ribeira Belt (Quirino Complex); (3) Cabo Frio Terrane (Região dos Lagos Complex). Neoproterozoic metassediments (white): (I) Andrelândia Megassequence; (II) Costeiro Domain of Ribeira Belt; Data from: (1) Duarte et al. (1997); (2) André et al. (2009); (3) Heilbron et al. (2013). 
2010, Alkmim \& Teixeira 2017) and compatible with the available U-Pb data for this unit (Heilbron et al. 2010, Machado et al. 1996, Silva et al.2002, Noce et al.2007, Degler et al. 2018, Kuribara et al. 2019).

\section{CONCLUSIONS}

The obtained geochemical and isotopic data reinforce the idea that the orthogranulites of the JFC had a very complex and protracted tectonic evolution, recording several tectonic events throughout the Proterozoic. The oldest event of Rhyacian age points out to an arc setting that produced juvenile to slightly contaminated tholeiitic to calc-alkaline rocks. This was followed by collision or either post-collision episodes, given by more evolved (granitic) rocks. Altogether, these rocks integrate part of a dismembered Rhyacian orogenic belt hidden within the Neoproterozoic Ribeira belt (Heilbron et al. 2008, 2010, Silva et al. 2002, Degler et al. 2018, Kuribara et al. 2019). Minor contribution from Archean material participated in the evolution of the magmatic arc, as indicated by a few $\mathrm{T}_{\mathrm{DM}}$ model ages of ca 2.75 to $2.58 \mathrm{Ga}$ and $\varepsilon$ nd values of -6.61 to -5.91 .

The new data are potentially important for Paleoproterozoic reconstruction models, due to the predominantly juvenile character of the Rhyacian JFC, as similarly observed in other belts of Brazil and worldwide.

On the other hand, some of the large deformed layers of the basic granulites point out to extensional settings that could be related to the opening of rift to passive margin sequences, possibly correlated with the Statherian Espinhaço Supergroup or either to the Meso-Neoproterozoic rift to passive margin basins development (Carandaí rift and/or Andrelândia basin).

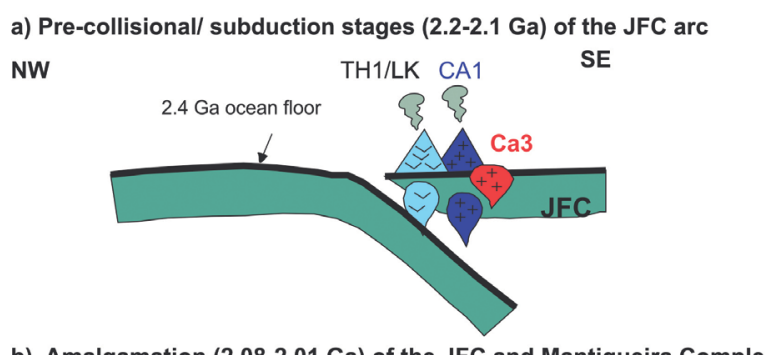

b) Amalgamation (2.08-2.01 Ga) of the JFC and Mantiqueira Complex

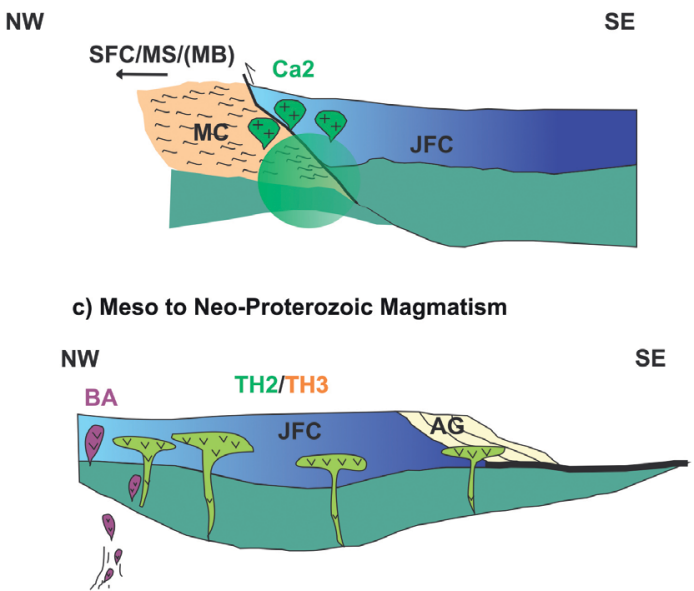

SFC: São Francisco paleoplate; MC: Mantiqueira Complex; JFC: Juiz de Fora Complex; AG: Andrelândia Group.

Figure 15. Envisaged tectoni $c$ evolution of the JFC in the focused area: (A) subduction stages of Juiz de Fora arc, focusing on the groups proposed on this work: LK/TH1- shallower melting and CA1- deeper melting; (B) docking of the JFC terrane to the border of the older Archean active margin represented by Mantiqueira Complex, with the formation of CA2 group: syn-collisional granitoids; (C) Basic alkaline magmatism (BA group) on JFC related to the Statherian Taphrogenesis and Basic magmatism possibly related to the opening of Carandaí and/or Andrelândia basins ( $\mathrm{TH} 2$ and $\mathrm{TH} 3$ groups).

Table 4. Petrographic, geochemical and isotopic data obtained for the studied orthogranulites from Juiz de Fora Complex.

\begin{tabular}{|c|c|c|c|c|c|c|}
\hline $\begin{array}{l}\text { Geochemical } \\
\text { groupings }\end{array}$ & Essential Mineralogy & Protholith & $\begin{array}{l}\text { Tectonic } \\
\text { Settings }\end{array}$ & U-Pb age & $\mathbf{T}_{\mathrm{DM}}$ & Tectonic Event \\
\hline $\mathrm{TH} 1+\mathrm{BK}$ & plg,opx,cpx,hbl, bt \pm kf & $\begin{array}{c}\text { Gabbros to } \\
\text { diorites }\end{array}$ & IAT & $2.2 \mathrm{Ga} ?$ & $2.48-2.27 \mathrm{Ga}$ & Rhyacian Subduction \\
\hline CA1 & plg,opx,qtz,cpx. Hbl,bt \pm kf & $\begin{array}{l}\text { Diorites to } \\
\text { tonalites }\end{array}$ & VAG & $2.1 \mathrm{Ga}$ & $\begin{array}{c}2.75-2.6 \mathrm{Ga} \\
2.5-2.2 \mathrm{Ga} \\
1.93 \mathrm{Ga}\end{array}$ & $\begin{array}{l}\text { Rhyacian Subduction } \\
\text { Archean inheritance }\end{array}$ \\
\hline CA3 & qtz,plg,opx,kf, bt \pm hbl & $\begin{array}{c}\text { Tonalites to } \\
\text { granites }\end{array}$ & $\begin{array}{l}\text { VAG- } \\
\text { intraplate }\end{array}$ & $?$ & $\begin{array}{c}2.64 \mathrm{Ga}-2.39- \\
1.9 \mathrm{Ga}\end{array}$ & $\begin{array}{l}\text { Late Rhyacian Subduction } \\
\text { Archean inheritance }\end{array}$ \\
\hline CA2 & plg,qtz,kf \pm opx,bt,hbl & Granites & $\begin{array}{l}\text { VAG-Syn- } \\
\text { collisional }\end{array}$ & $2.08 \mathrm{Ga}$ & $2.31-2.03 \mathrm{Ga}$ & Rhyacian Subduction-Collision \\
\hline BA & $o p x+c p x+p l g+b t+h b l+q t z$ & Gabbros & Intra-plate & $1.76 \mathrm{Ga}$ & $2.51-2.21 \mathrm{Ga}$ & Sthaterian Extension \\
\hline $\mathrm{TH} 2$ & & & E-MORB & $?$ & $1.74-1.73 \mathrm{Ga}$ & $\begin{array}{c}\text { Meso-Neoproterozoic } \\
\text { Extension? }\end{array}$ \\
\hline & $o p x+c p x+p l g+h b l+g r d$ & Gabbros & & & & \\
\hline TH3 & & & N-MORB & $?$ & $1.87 \mathrm{Ga}$ & $\begin{array}{c}\text { Meso-Neoproterozoic } \\
\text { Extension? }\end{array}$ \\
\hline
\end{tabular}




\section{ACKNOWLEDGEMENTS}

The first author thanks the Coordenação de Aperfeiçoamento de Pessoal de Nível Superior for the Geosciences Graduate Program scholarship. The authors acknowledge the support of the Laboratório de Processamento de Amostras (LGPA) and Laboratório de Geocrononologia e Isótopos Radiogênicos (LAGIR) of Universidade do Estado do Rio de Janeiro (UERJ), the CNPq grants of Monica Heilbron, Claudio Valeriano and Wilson Teixeira, and FAPERJ-CNE for funding the research.

\section{ARTICLE INFORMATION}

Manuscript ID: 20190007. Received on: 02/07/2019. Approved on: 07/16/2019.

LEA collected geological data on field work, obtained, processed and interpreted analytical data, wrote the manuscript, prepared all figures, maps and diagrams, and discussed all data. MH wrote the manuscript, reviewed all manuscript and contributed with Discussions. WT reviewed all manuscript and contributed with Discussion. CV reviewed all manuscript and contributed with Discussions. CN processed Nd and Sr data analysis.

Competing interests: The authors declare no competing interests.

\section{REFERENCES}

Alkmim F.F. \& Teixeira W. 2017. The Paleoproterozoic Mineiro Belt and the Quadrilátero Ferrífero. In: Heilbron M., Cordani U., Alkmim F.F. (eds.), São Francisco Craton, Eastern Brazil: Tectonic Genealogy of a Miniature Continent. Regional Geology Reviews. New York, Springer, p. 71-94.

Allègre C.J., Poirier J.P., Humler E., Hofmann A.W. 1995. The chemical composition of the Earth. Earth Planetary Science Letters, 134(3-4):515-526. https://doi.org/10.1016/0012-821X(95)00123-T

Almeida J.C.H., Tupinambá M, Heilbron M., Trouw R. 1998. Geometric and kinematic analysis at the Central Tectonic Boundary of the Ribeira belt, Southeastern Brazil. In: Congresso Brasileiro de Geologia. Anais... Sociedade Brasileira de Geologia, v. 39, p. 32.

André J.L.F., Valladares C.S., Duarte BP. 2009. O Complexo Juiz de Fora na região de Três Rios (RJ): Litogeoquímica, geocronologia U-Pb (LA-ICPMS) e geoquímica isotópica de Nd e Sr. Revista Brasileira de Geociências, 39(4):773-793.

Babinski M., Brito-Neves B.B., Machado N., Noce C.M., Uhlein A., Van Schmus W.R., 1994. Problema na metodologia U/Pb em zircões de vulcânicas continentais: o caso do Grupo Rio dos Remédios, Supergrupo Espinhaço, no Estado da Bahia. In: $38^{\circ}$ Congresso Brasileiro de Geologia. Boletim de Resumos Expandidos... SBG, Camboriú, 2, p. 409-410.

Barbosa N.S., Teixeira W., Ávila C.A., Montecinos P.M., Bongiolo E.M., Vasconcellos F.F. 2018. U-Pb geochronology and coupled Hf-Nd-Sr isotopicchemical constraints of the Cassiterita Orthogneiss (2.47-2.41-Ga) in the Mineiro belt, São Francisco craton: Geodynamic fingerprints beyond the Archean-Paleoproterozoic Transition. Precambrian Research, 326:399-416. https://doi.org/10.1016/j.precamres.2018.01.017

Bellieni G., Comin-Chiaramonti P., Marques L.S., Melfi A.J., Piccirilo E.M., Nardy A.J.R., Roisemberg A. 1984. High and low $\mathrm{TiO}_{2}$ flood-basalts from the Parana Plateau (Brazil): petrology and geochemical aspects bearing on their mantle origin. Neues Jahrbuch für Mineralogie Abhandlungen, 150:273-306.

Bento dos Santos T., Munhá J.M., Tassinari C.G.G., Fonseca P.E., Dias Neto C. 2011. Metamorphic P-T evolution of granulites in the central Ribeira Fold Belt, SE Brazil, Geosciences Journal, 15(1):27-51. https://doi.org/10.1007/ s12303-011-0004-1

Boynton W.V. 1984. Cosmochemistry of the rare earth elements; meteorite studies. In: Henderson P. (ed.). Rare earth element geochemistry. Amsterdam, Elsevier, p. 63-114.

Brito-Neves B.B., Sá J.M., Nilson A.A., Botelho N.F. 1995. A Tafrogênese Estateriana nos blocos paleoproterozóicos da América do Sul e processos subsequentes. Geonomos, 3(2):1-21. http://dx.doi.org/10.18285/ geonomos.v3i2.205

Cameron W.E., Nisbet E.G., Dietrich V.J. 1979. Boninites, komatiites and ophiolitic basalts. Nature, 280:550-553. https:// doi.org/10.1038/280550a0

Cardoso C.D., Ávila C.A., Neumann R., Oliveira E.P., Valeriano C.M., Dussin I. 2019. A Rhyacian continental arc during the Evolution of the Mineiro belt, Brazil: constraints from the Rio Grande and Brumado metadiorites. Lithos, 326-327:246-264. https://doi.org/10.1016/j.lithos.2018.12.025
Chemale Jr. F., Dussin I.A., Alkmim F.F., Martins M.S., Queiroga G., Armstrong R., Santos M.N. 2012. Unravelling a Proterozoic basin history through detrital zircon geochronology: the case of the Espinhaço Supergroup, Minas Gerais, Brazil. Gondwana Research, 22(1):200-206. https://doi.org/10.1016/j.gr.2011.08.016

Cheng Q.C., Macdougall J.D., Lugmair G.W. 1993. Geochemical studies of Tahiti, Taehitia and Mehetia, Society island chain. Journal of Volcanology and Geothermal Research, 55(1-2):155-184. https://doi. org/10.1016/0377-0273(93)90096-A

Cordani U.G., Delhal J., Ledent D. 1973. Orogenéses superposées dans le précambrien du Brésil SudOriental (Etats de Rio de Janeiro et Minas Gerais). Revista Brasileira de Geociências, 3(1):1-22.

Costa A.G. 1998. The granulite-facies rocks of the northern segment of the Ribeira Belt, eastern Minas Gerais, SE Brazil. Gondwana Research, 1(3-4):367-372. https://doi.org/10.1016/S1342-937X(05)70852-2

Cox K.G., Bell J.D., Pankhurst R.J. 1979. The interpretation of igneous rocks. London, Allen and Unwin, $450 \mathrm{p}$.

Crawford A.J., Falloon T.J., Green D.H. 1989. Classification, petrogenesis and tectonic setting of boninites. In: Crawford A.J. (ed.). Boninites. London: Unwin-Hyman, p. 1-49.

Cutts K., Lana C. 2019. The comples tale of Mantiqueira and Juiz de Fora: A comment on "Eoarchean to Neoproterozoic crustal evolution of the Mantiqueira and the Juiz de For a Complexes, SE Brazil: Petrology, geochemistry, zircon U-Pb geochronology and Lu-Hf isotopes". Precambrian Research, 332(105305):1-3.

Degler R., Pedrosa-Soares A.C., Novo T., Tedeschi M., Silva L.C., Dussin I., Lana C. 2018. Rhyacian-Orosirian isotopic records from the basement of the Araçuaí-Ribeira orogenic system (SE Brazil): Links in the Congo-São Francisco paleocontinent. Precambrian Research, 317:179-195. http://doi. org/10.1016/j.precamres.2018.08.018

Delhal J., Ledent D., Cordani U.G. 1969. Ages Pb/U; Sr/Rb el Ar/K de Formations Metamorphiques et Granitique du Sud-Est du Brasil (Etats de Rio de Janeiro e Minas Gerais). Annales de la Societé Geologiqué Belgique, 92:271-283.

DePaolo D.J. 1981. A neodymium and strontium isotopic study of the Mesozoic calc-alkaline granitic batholiths of the Sierra Nevada and Peninsular Ranges, California. Journal of Geophysical Research: Solid Earth, 86:10470-10488.

DePaolo D.J. 1988. Neodymium isotope geochemistry: an introduction. Berlim, Springer-Verlag, $187 \mathrm{p}$

Dessimoz M., Müntener O., Ulmer P. 2012. A case for hornblende dominated fractionation of arc magmas: the Chelan complex (Washington Cascades). Contributions to Mineralogy and Petrology, 163(4):567-589. https://doi.org/10.1007/s00410-011-0685-5

Duarte B.P., Figueiredo M.C.H., Campos Neto M., Heilbron M. 1997. Geochemistry of the granulite fácies orthogneisses of Juiz de Fora Complex, Central Segment of the Ribeira Belt, Southeastern Brazil. Revista Brasileira de Geociências, 27(1):67-82. http://doi. org/10.25249/0375-7536.19976782 
Duarte B.P., Heilbron M., Campos Neto M.C. 2000. Granulite/charnockite from the Juiz de Fora Domain, central segment of the Brasiliano-Pan-African Ribeira belt. Revista Brasileira de Geociências, 30(3):358-362. http://doi. org/10.25249/0375-7536.2000303358362

Duarte B.P., Valente S., Heilbron M., Campos Neto M.C. 2004. Petrogenesis of orthogneisses of the Mantiqueira Complex, Central Ribeira Belt, SE Brazil: an Archean to Paleoproterozoic basement unit reworked during the Pan-African Orogeny. Gondwana Research, 7(2):437-450. https://doi. org/10.1016/S1342-937X(05)70795-4

Dussin I.A. \& Dussin T.M. 1995. Supergrupo Espinhaço: Modelo de Evolução Geodinâmica. Geonomos, 3:19-26.

Faure G. 1986. Principles of Isotope Geology. 2a ed. New York, Wiley, 555 p.

Fischel D.P., Pimentel M.M., Fuck R.A., Costa A.G., Rosière C.A. 1998. Geology and Sm-Nd isotopic data for the Mantiqueira and Juiz de Fora Complexes (Ribeira Belt) in the Abre Campo Manhaçu region, Minas Gerais, Brazil. In: International Conference on Basement Tectonics. Abstracts... v.14, p. 21-23.

Frost B.R., Barnes C.G., Collins W.J., Arculus R.J., Ellis D.J., Frost C.D. 2001. A geochemical classification of granitic rocks. Journal of Petrology, 42(11):2033-2048. http://doi.org/10.1093/petrology/42.11.2033

Gonçalves L., Farina F., Lana C., Pedrosa-Soares A.C., Alkmim F., Nalini Jr H.A. 2014. New U-Pb ages and lithochemical attributes of the Ediacaran Rio Doce magmatic arc, Araçuaí confined orogen, Southeastern Brazil. Journal of South America Earth Science, 52:1-20. http://dx.doi.org/10.1016/j. jsames.2014.02.008

Goscombe B.D., Foster D.A., Gray D., Wade B., Marsellos A., Titus J. 2017. Deformation correlations, stress field switches and evolution of an orogenic intersection: the Pan-African Kaoko-Damara orogenic junction, Namibia. Geoscience Frontiers, 8(6):1187-1232. https://doi.org/10.1016/j. gsf.2017.05.001

Goscombe B.D., Gray D. 2007. The Coastal Terrane of the Kaoko Belt, Namibia: outboard arc-terrane and tectonic significance. Precambrian Research, 155(1-2):139-158. https://doi.org/10.1016/j. precamres.2007.01.008

Goscombe B.D., Gray D. 2008. Structure and strain variation at mid-crustal levels in a transpressional orogen: a review of Kaoko Belt structure and the character of West Gondwana amalgamation. Gondwana Research Focus Paper, 13(1):45-85. http://dx.doi.org/10.1016/j.gr.2007.07.002

Hanson G.N. 1980. Rare Earth elements in petrogenetic studies of igneous systems. Annual Review of Earth and Planetary Science, 8(1):371-406. http://dx.doi.org/10.1146/annurev.ea.08.050180.002103

Hasui Y., Carneiro C.D.R., Coimbra A.M. 1975. The Ribeira Fold Belt. Revista Brasileira de Geociências, 5(4):257-267.

Heilbron M. 1993. Evolução tectono-metamórfica da Seção Bom Jardim de Minas (MG) - Barra do Piraí (RJ). Setor Central da Faixa Ribeira. Tese de Doutorado, Instituto de Geociências, Universidade de São Paulo, São Paulo, 268 p.

Heilbron M., Cordani U., Alkmim F., Reis H. 2017. Tectonic Genealogy of a Miniature Continent. In: Heilbron M., Cordani U.G., Alkmim F.F. (eds.). São Francisco Craton, Eastern Brazil: Tectonic Genealogy of a Miniature Continent. Regional Geology Reviews. New York, Springer, p. 321-330.

Heilbron M., Duarte B.P., Valeriano C.M., Simonetti A., Machado N., Nogueira J.R. 2010. Evolution of reworked Paleoproterozoic basement rocks within the Ribeira belt (Neoproterozoic), SE-Brazil, based on $\mathrm{U} / \mathrm{Pb}$ geochronology: Implications for paleogeographic reconstructions of the São Francisco-Congo paleocontinent. Precambrian Research, 178(1):136-148. http://dx.doi.org/10.1016/j.precamres.2010.02.002

Heilbron M., Euzébio R., Peixoto C., Tupinambá M., Guia C., Peternel R., Silva L.G., Ragatky C.D. 2013. O Complexo Juiz de Fora na Folha Santo Antônio de Pádua 1:100.000: geologia e geoquímica. Geociências, 32(1):10-23.

Heilbron M., Machado R., Figueiredo M.C.H. 1997. Lithogeochemistry of paleoprotezoic orthogranulites from Rio Preto (MG) - Vassouras (RJ) region, central Ribeira Belt. Revista Brasileira de Geociências, 27(1):83-99. http://doi.org/10.25249/0375-7536.19978398
Heilbron M., Mohriak W.U., Valeriano C.M., Milani E., Almeida J.C.H., Tupinambá M. 2000. From Collision to Extension: The Roots of the Southeastern Continental Margin of Brazil. In: Mohriak W.U., Talwani M. (eds.). Atlantic Rifts and Continental Margins. AGU, v. 115, p. 1-32.

Heilbron M., Oliveira C., Lobato M., Valeriano C.M., Dussin I., Dantas E., Simonetti A., Bruno H., Corrales F., Socoloff E. 2019. The Barreiro suite in the central Ribeira Belt (SE-Brazil): a late Tonian tholeiitic intraplate magmatic event in the distal passive margin of the São Francisco Paleocontinent. Brazilian Journal of Geology, 49(2):1-19. http://dx.doi. org/10.1590/2317-4889201920180129

Heilbron M., Pedrosa-Soares A.C., Campos Neto M., Silva L.C., Trouw R.A.J., Janasi V.C. 2004. A Província Mantiqueira. In: Mantesso-Neto V., Bartorelli A., Carneiro C.D.R., Brito-Neves B.B. (eds.). O desvendar de um continente: a moderna geologia da América do Sul e o legado da obra de Fernando Flávio Marques de Almeida. São Paulo, Editora Beca, p. 203-234.

Heilbron M., Tupinambá M., Almeida J.C.H., Valeriano C.M., Valladares C.S., Duarte B.P. 1998. New constraints on the tectonic organization and structural styles related to the Brasiliano collage of the central segment of the Ribeira belt, SE Brazil. In: International Conference on Precambrian and Craton Tectonics/International Conference on Basement Tectonics. Extended Abstracts... Ouro Preto, v. 14, p. 15-17.

Heilbron M., Valeriano C.M., Tassinari C.C.G., Almeida J.C.H., Tupinambá M., Siga Jr. O., Trouw R.A.J. 2008. Correlation of Neoproterozoic terranes between the Ribeira Belt, SE Brazil and its African counterpart: comparative tectonic evolution and open questions. In: Pankhurst R.J., Trow R.A.J., Brito-Neves B.B., De Witt M.J. (eds.). West Gondwana: Pre-Cenozoic Correlations across the South Atlantic Region. London, Geological Society, Special Publication, 294, p. 211-232.

Irvine T.M. \& Baragar W.R. 1971. A guide to the chemical classification of common volcanic rocks. Canadian Journal of Earth Sciences, 8(5):523-548. https://doi.org/10.1139/e71-055

Janoušek V., Farrow C.M., Erban V. 2006. Interpretation of whole-rock geochemical data in igneous geochemistry: introducing Geochemical Data Toolkit (GCDkit). Journal of Petrology, 47(6):1255-1259. https://doi. org/10.1093/petrology/egl013

Kuribara Y., Tsunogae T, Takamura Y, Santosh M, Takamura Y, Costa A, Rosiére C. 2019. Eoarchean to Neoproterozoic crustal evolution of the Mantiqueira and the Juiz de Fora Complexes, SE Brazil: Petrology, geochemistry, zircon $\mathrm{U}-\mathrm{Pb}$ geochronology and Lu-Hf isotopes. Precambrian Research, 323:82-101. http://dx.doi.org/10.1016/j.precamres.2019.01.008

Machado N., Valladares C., Heilbron M., Valeriano C.M. 1996. U-Pb geochronology of the central Ribeira Belt (Brazil) and implications for the evolution of the Brazilian Orogeny. Precambrian Research, 79(3-4):347-361. https://doi.org/10.1016/0301-9268(95)00103-4

Meschede M. 1986. A method of discriminating between different types of mid-ocean ridge basalts and continental tholeiites with the Nb-Zr-Y diagram. Chemical Geology, 56(3-4):207-218. https://doi. org/10.1016/0009-2541(86)90004-5

Miller R. McG. 1983. The Pan-African Damara Orogen of Southwest Africa/ Namibia. In: Miller R. McG. (ed.). Evolution of the Damara Orogen. Special Publication of the Geological Society of South Africa, v. 11, p. 431-515.

Noce C., Pedrosa-Soares A.C., Silva L.C., Armstrong R., Piuzana D. 2007. Evolution of polycyclic basement complexes in the Araçuaí Orogen, based on U-Pb SHRIMP data: Implications for Brazil Africa links in Paleoproterozoic time. Precambrian Research, 159(1):60-78. http://dx.doi. org/10.1016/j.precamres.2007.06.001

Pearce J.A. \& Gale G.H. 1977. Identification of ore-deposition environment from trace-element geochemistry of associated igneous host rocks: Geological Society, London, Special Publication, 7:14-24. https://doi. org/10.1144/GSL.SP.1977.007.01.03

Pearce J.A., Harris N.W., Tindle A.G. 1984. Trace element discrimination diagrams for the tectonic interpretation of granitic rocks. Journal of Petrology, 25(4):956-983

Peate D.W., Hawkesworth C.J., Mantovani M.S.M. 1992. Chemical stratigraphy of the Parana lavas (South America): classification of magmatypes and their spatial distribution. Bulletim of Volcanology, 55(1-2):119-139. https://doi.org/10.1007/BF00301125 
Peccerillo A. \& Taylor S.R. 1976. Geochemistry of Eocene calc-alkaline volcanic rocks from the Kastamonu area, Northern Turkey. Contribution to Mineralogy and Petrolology, 58(1):63-81. https://doi.org/10.1007/ BF00384745

Pedrosa-Soares A.C. \& Alkmim F.F. 2011. How many rifting events preceded the development of the Araçuaí-West Congo orogen? Geonomos, 19(2):244-251. http://doi.org/10.18285/geonomos.v19i2.56

Pedrosa-Soares A.C. \& Noce C.M. 1998. Where is the suture zone of the Neoproterozoic Aracuaí-West-Congo orogen? In: 14th International Conference of Basement Tectonics. Expanded abstracts... Ouro Preto, Universidade Federal de Ouro Preto, p. 35-37.

Pedrosa-Soares A.C., Alkmim F.F., Tack L., Noce C.M., Babinski M., Silva L.C., Martins-Neto M.A. 2008. Similarities and differences between the Brazilian and African counterparts of Neoproterozoic Araçuaí-West Congo orogen. In: Pankhrust R., Trouw R., Brito-Neves B.B., De Witt, M.J. (eds.). The Gondwana Peleocontinent in the South Atlantic Region. Geological Society of London, Special Publications, v. 294, p. 153-172.

Pedrosa-Soares A.C., Noce C.M., Wiedemann C.M., Pinto C.P. 2001. The Araçuaí-West Congo orogen in Brazil: An overview of a confined orogen formed during Gondwanland assembly. Precambrian Research, 110(1):307-323. http://doi.org/10.1016/S0301-9268(01)00174-7

Pedrosa-Soares A.C., Wiedmann-Leonardos C.M. 2000. Evolution of the Araçuaí Belt and its connections to the Ribeira Belt. In: Cordani U.G., Milani E.J., Thomaz Filho A., Campos, D.A. (eds.). Tectonic Evolution of South America. Rio de Janeiro, IGC Brasil, p. 265-288.

Ragatky D., Tupinamba M., Heilbron M., Duarte B.P, Valladares C. 1999. New $\mathrm{Sm} / \mathrm{Nd}$ isotopic data from pre-1.8 Ga basement rocks of central Ribeira Belt, SE Brazil. In: $2^{\circ}$ South American Symposium on Isotope Geology. Expanded abstracts ... Córdoba, Argentina, p. 433-436.

Ribeiro A., Teixeira W., Dussin I.A., Avila C.A., Nascimento D. 2013. UPbLA-ICP-MS detrital zircon ages of the São João del Rei and Carandaí basins: new evidence of intermittent Proterozoic rifting in the São Francisco paleocontinent. GondwanaResearch, 24:713-726.

Santos C.O. 2017. Caracterização Geoquímica, Isotópica E Idade U-Pb Da Suite Barreiro, Domínio Juiz De Fora, Faixa Ribeira, MG. Tese, Universidade do Estado do Rio de Janeiro, Rio de Janeiro, 120 p.

Santos M.N., Chemale Jr. F., Dussin I.A., Martins M.S., Queiroga G., Pinto R.T.R., Santos A.N., Armstrong R. 2015. Provenance and paleogeographic reconstruction of a mesoproterozoic intracratonic sag basin (Upper Espinhaço Basin, Brazil). Sedimentary Geology, 318:40-57. http://dx.doi. org/10.1016/j.sedgeo.2014.12.006

Schmitt R.S., Trouw R.A.J., Van Schmus W.R., Pimentel M.M. 2004. Late amalgamation in the central part of Western Gondwana: new geochronological data and the characterization of a Cambrian collision orogeny in the Ribeira belt (SE Brazil). Precambrian Research, 133(1):29-61. http://dx.doi.org/10.1016/j.precamres.2004.03.010

Seth B., Kröner A., Mezger K., Nemchin A.A, Pidgeon R.T, Okrusch M. 1998. Archaean to Neoproterozoic magmatic events in the Kaoko belt of NW Namibia and their geodynamic significance. Precambrian Research, 92(4):341-363. https://doi.org/10.1016/S0301-9268(98)00086-2

Shand S.J. 1943. Eruptive Rocks. 2a ed. New York, John Wiley, 444 p.

Silva L.C., Noce C.M., Carneiro M.A., Pimentel M., Pedrosa-Soares A.C., Leite C.A., Vieiro V.S., Paes V.J.C., Cardoso Filho J.M., Silva M.A. 2002. Reavaliação da evolução geológica em terrenos Pré-Cambrianos Brasileiros com base em novos dados U-Pb SHRIMP, Parte II: Orógeno Araçuaí, Cinturão Mineiro e Cráton São Francisco Meridional em Minas Gerais. Revista Brasileira de Geociências, 32(4):513-528.

Smithies R.H., Champion D.C., Sun S-.S. 2004. Early evidence for LILEenriched mantle source regions: diverse magmas from the c. 3.0 Ga Mallina Basin, Pilbara Craton, NW Australia. Journal of Petrology, 45(8):1515-1537. http://doi.org/10.1093/petrology/egh014
Streckeisen A. 1974. Classification and nomenclature of plutonic rocks: Recommendations of the IUGS subcommission on the systematics of igneous rocks. Geologische Rundschau, 63(2):773-786. https://doi. org/10.1007/BF01820841

Sun S.-S. \& Nesbitt R.W. 1978. Geochemical regularities and genetic significance of ophiolitic basalts. Geology, 6(11):689-693. https://doi. org/10.1130/0091-7613(1978)6\%3C689:GRAGSO\%3E2.0.CO;2

Tanaka T., Togashi S., Kamioka H., Amakawa H., Kagami H., Hamamoto T., Yuhara M., Orihashi Y., Yoneda S., Shimizu H., Kunimaru T., Takahashi K., Yanagi T., Nakano T., Fujimaki H., Shinjo R., Asahara Y., Tanimizu M., Dragusanu C. 2000. JNdi-1: a neodymium isotopic reference in consistency with La Jolla neodymium. Chemical Geology, 168(3-4):279-281. https:// doi.org/10.1016/S0009-2541(00)00198-4

Teixeira W., Ávila C.A., Bongiolo E.M., Hollanda M.H.B.M., Barbosa N.S. 2014. Age and tectonic significance of the Ritápolis batholith, Mineiro belt (Southern São Francisco Craton): U-Pb LA-ICPMS, Nd isotopes and geochemical evidence. In: $9^{\circ}$ South American Symposium on Isotope Geology - SSAGI, São Paulo, Brazil. Program and Abstracts... p. 225.

Teixeira W., Ávila C.A., Dussin I.A., Corrêa Neto A.V., Bongiolo E.M., Santos J.O., Barbosa N.S. 2015. Juvenile accretion episode (2.35-2.32 Ga) in the Mineiro belt and its role to the Minas accretionary orogeny: Zircon $\mathrm{U}-\mathrm{Pb}-\mathrm{Hf}$ and geochemical evidences. Precambrian Research, 256:148-169. http://dx.doi.org/10.1016/j.precamres.2014.11.009

Trouw R.A.J., Heilbron M., Ribeiro A., Paciullo F.V.P., Valeriano C.M., Almeida J.C.H., Tupinambá M., Andreis R.R. 2000. The Central Segment of the Ribeira Belt. In: Cordani U.G., Milani E.J., Thomaz-Filho A., Campos D.A. (eds.). Tectonic Evolution of South America, Rio de Janeiro. 31st International Geological Congress, p. 287-310.

Tupinambá M., Heilbron M., Duarte B.P., Nogueira J.R., Valladares C., Almeida J.C.H., Silva L.G.E., Medeiros S.R., Almeida C.G., Miranda A.W.A., Ragatky C.D., Mendes J., Ludka I. 2007. Geologia da Faixa Ribeira Setentrional: Estado da Arte e Conexões com a Faixa Aracuaí. Geonomos, 15(1):67-79. http://doi.org/10.18285/geonomos.v15i1.108

Tupinambá M., Teixeira W., Heilbron M. 2000. Neoproterozoic Western Gondwana assembly and subduction-related plutonism: the role of the Rio Negro Complex in the Ribeira Belt, South-eastern Brazil. Revista Brasileira Geociências, 30(1):7-11.

Tupinambá M., Teixeira W., Heilbron M.2012. Evolução Tectônica e Magmática da Faixa Ribeira entre o Neoproterozoico e o Paleozoico Inferior na Regiao Serrana do Estado do Rio de Janeiro, Brasil. Anuário do Instituto de Geociências da UFRJ, 35(2):140-151.https://doi.org/10.11137/2012_2_140_151

Valeriano C.M., Vaz G.S., Medeiros S.R., Neto C.C.A., Ragatky C.D. 2008. The Neodymium isotope composition of the JNdi-1 oxide reference material: results from the LAGIR Laboratory, Rio de Janeiro. In: VI South American Symposium on Isotope Geology. Proceedings... San Carlos de Bariloche, Argentina, p. 1-2. (CD-ROM)

Valladares C.S., Duarte B.P., Heilbron M., Ragatky C.D. 2000. The tectonomagmatic evolution of the western terrane and the Paraíba do Sul klippe of the Neoproterozoic Ribeira orogenic belt, southeastern Brazil. Revista Brasileira de Geociências, 30(1):1-6.

Valladares C.S., Souza S.F., Ragatky C.D. 2002. The Quirino Complex: a Transamazonian Magmatic Arc of the Central Segment of the Brasiliano/ Pan-African Ribeira Belt, SE Brazil. Revista Universidade Rural: Série Ciências Exatas e da Terra, Rio de Janeiro, 21(1):49-61.

Verma S.P., Guevara M., Agrawal S. 2006. Discriminating four tectonic settings: Five new geochemical diagramsfor basic and ultrabasic volcanic rocks based on log-ratio transformation of major-element data. Journal of Earth System Science, 115(5):485-528. http://doi.org/10.1007/ BF02702907

Wilson M. 1989. Igneous Petrogenesis. London, Unwin Hyman.

Wise S.A. \& Waters R.L. 2007. Certificate of Analysis Standard Reference Material ${ }^{\circledast} 987$ Strontium Carbonate (Isotopic Standard). NIST National Institute of Standards \& Technology. $2 \mathrm{p}$. 